\title{
Small farms and development in sub-Saharan Africa: Farming for food, for income or for lack of better options?
}

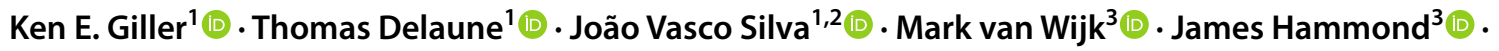

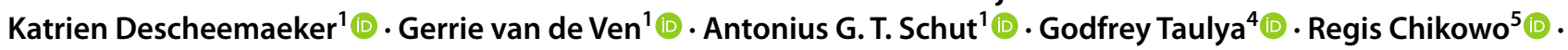 \\ Jens A. Andersson ${ }^{1}$ (i)
}

Received: 17 March 2021 / Accepted: 6 August 2021 / Published online: 15 October 2021

(c) The Author(s) 2021

\begin{abstract}
Most food in sub-Saharan Africa is produced on small farms. Using large datasets from household surveys conducted across many countries, we find that the majority of farms are less than $1 \mathrm{ha}$, much smaller than previous estimates. Farms are larger in farming systems in drier climates. Through a detailed analysis of food self-sufficiency, food and nutrition security, and income among households from divergent farming systems in Ethiopia, Ghana, Mali, Malawi, Tanzania and Uganda, we reveal marked contrasts in food security and household incomes. In the south of Mali, where cotton is an important cash crop, almost all households are food secure, and almost half earn a living income. Yet, in a similar agroecological environment in northern Ghana, only $10 \%$ of households are food secure and none earn a living income. Surprisingly, the extent of food insecurity and poverty is almost as great in densely-populated locations in the Ethiopian and Tanzanian highlands that are characterised by much better soils and two cropping seasons a year. Where populations are less dense, such as in South-west Uganda, a larger proportion of the households are food self-sufficient and poverty is less prevalent. In denselypopulated Central Malawi, a combination of a single cropping season a year and small farms results in a strong incidence of food insecurity and poverty. These examples reveal a strong interplay between population density, farm size, market access, and agroecological potential on food security and household incomes. Within each location, farm size is a major determinant of food self-sufficiency and a household's ability to rise above the living income threshold. Closing yield gaps strongly increases the proportion of households that are food self-sufficient. Yet in four of the locations (Ethiopia, Tanzania, Ghana and Malawi), land is so constraining that only $42-53 \%$ of households achieve food self-sufficiency, and even when yield gaps are closed only a small proportion of households can achieve a living income. While farming remains of central importance to household food security and income, our results help to explain why off-farm employment is a must for many. We discuss these results in relation to sub-Saharan Africa's increasing population, likely agricultural expansion, and agriculture's role in future economic development.
\end{abstract}

Keywords Farm size $\cdot$ Yield gaps $\cdot$ Agroecological zones $\cdot$ Living income $\cdot$ Sustainable intensification

Ken E. Giller

ken.giller@wur.nl

1 Plant Production Systems, Wageningen University, PO Box 430, 6700AK Wageningen, The Netherlands

2 International Maize and Wheat Improvement Center (CIMMYT), Harare, Zimbabwe

3 International Livestock Research Institute (ILRI), PO Box 30709, Nairobi 00100, Kenya

4 International Institute of Tropical Agriculture (IITA), PO Box 7878, Kampala, Uganda

5 Crop Science Department, University of Zimbabwe, Harare, Zimbabwe

\section{Introduction}

The farming activities of rural households provide the bedrock of the food system in sub-Saharan Africa (FAO et al., 2020), and are key to achieving the Sustainable Development Goals 1 - Zero Poverty and 2 - Zero Hunger (United Nations, 2015). Yet a large proportion of these households are themselves food insecure (Frelat et al., 2016) and fall below the poverty line (Harris, 2019; Harris \& Orr, 2013). Agricultural productivity has increased far more slowly in sub-Saharan Africa than in other regions of the world (Giller et al., 2021), and crops 
yield only some $20 \%$ of what could be achieved (Sanchez, 2002; van Ittersum et al., 2016). A primary reason for the large yield gaps is the poor soil fertility status which results from continuous cropping without replenishment of the nutrients removed in harvested produce (Buresh et al., 1997; Sanchez, 2002). Against this backdrop, the population is growing rapidly (United Nations, 2019) and the impacts of climate change are already being felt (Godfrey \& Tunhuma, 2020). The large yield gaps and the rapid growth in demand for nutritious food present opportunities to increase agricultural output for these expanding internal markets. Yet agricultural productivity remains stagnant. Smallholders are reluctant to invest in their small farms due to the meagre returns in food and farm income they can generate (Franke et al., 2014; Ritzema et al., 2017), turning their focus instead to offfarm opportunities to provide for their families. This situation, coined as the 'food security conundrum' (Giller, 2020), frustrates initiatives to support the sustainable intensification urgently needed (Gerard, 2020) to provide for both local and national food and income security.

This article analyses this stylized, general image of Africa's food security situation and impeded sustainable intensification, exploring regional differences and local differentiation between farming households. Impacts of narrowing yield gaps on food security and income of very small farms have not been assessed to date across diverse farming systems in SSA, with the exception of a few case studies (Franke et al., 2014; Harris, 2019; Ritzema et al., 2017). Earlier analyses (e.g. Hengsdijk et al., 2014) suggested a strong relationship between agroecological conditions and farm size. They found that median farm sizes were substantially smaller in East Africa with bimodal rainfall than in countries of West and southern Africa where only a single cropping season was possible each year. To explore whether this observation holds more generally across sub-Saharan Africa, we analysed available datasets from the Living Standards Measurements Surveys (LSMS) in which rural households had been sampled using stratified sampling over complete countries in relation to agroecological zones.

Second, we analyse the current status of households in terms of food self-sufficiency, food and nutrition security, and income from contrasting locations in East, West and southern Africa. We focus on locations where farming systems have been analysed in detail, examining examples from the different geographies in East African highlands (the southern highlands of Ethiopia, south-west Uganda and the West Usambara Mountains of Tanzania), the Sudano-Sahelian in West Africa (southern Mali, the Upper East region of Ghana), and southern Africa (Lilongwe plains of central Malawi). Having described the current status of the households we then explore the impact of closing crop yield gaps on the household indicators, the role of market opportunities and consider the issue of potential future expansion of the area under agriculture.

\section{Materials and Methods}

\subsection{Country-wide agricultural household data and agroecological zones}

A total 35,292 agricultural households were assessed from nationally representative surveys performed in nine sub-Saharan African countries between 2005 and 2014 (Table 1, Fig. 1). Household data were retrieved from the World Bank LSMS-ISA (Living Standard Measurement Surveys - Integrated Surveys on Agriculture) (Kilic et al., 2015) data library (World Bank, 2020) and from the FAO RuLIS (Rural Livelihoods Information System) microdata library (FAO, 2018). RuLIS provides harmonised indicators from a variety national household surveys. For Ghana, Kenya, Mali, and Niger, only households considered to be agricultural households in the RuLIS data library were selected for analysis. Agricultural households are defined as those for whom agricultural activities contribute to at least $30 \%$ of total household income. Household data from the LSMS-ISA surveys were extracted for Ethiopia, Malawi, Nigeria, Tanzania, and Uganda. All households in the LSMS-ISA surveys were included as these surveys focus only on agriculture and rural development. Among the available indicators of farmer-reported cultivated land area and tenure status, we selected a common farm area (ha) indicator, defined as the sum of agricultural land used by the household to grow arable or perennial crops. Households which reported no farm area, but relied on agricultural activities for food and/or income were not included in the analysis.

The agroecological classification scheme of IFPRI (2015) for sub-Saharan Africa was used. The classification scheme is based on three variables: the major climate division (mean monthly temperature adjusted to sea level), the moisture zone (length of the growing period) and elevation (Table S1). Household surveys georeferenced at the enumeration area level (Table S2) allowed direct extraction of their corresponding agroecological zone information. When the administrative region was the sole indicator of the household location, all of the households were assigned to the dominant agroecological zone, in terms of area, corresponding to that region. Distributions of farm size were analysed using density plots for unique country $\times$ agroecological zone combinations. 
Table 1 Summary table of the selected farming systems of sub-Saharan Africa from the RHoMIS database (van Wijk et al., 2020)

\begin{tabular}{|c|c|c|c|c|c|c|}
\hline & $\begin{array}{l}\text { Ethiopian } \\
\text { Highlands }\end{array}$ & Northern Tanzania & $\begin{array}{l}\text { Ugandan } \\
\text { Highlands }\end{array}$ & Northern Ghana & $\begin{array}{l}\text { Cotton Basin } \\
\text { Mali }\end{array}$ & Central Malawi \\
\hline $\begin{array}{l}\text { Sample size } \\
\text { (no. households) }\end{array}$ & 177 & 95 & 88 & 319 & 64 & 130 \\
\hline $\begin{array}{l}\text { Location } \\
\text { (nearby city) }\end{array}$ & Sodo & Lushoto & Rakai & Navrongo & Koutiala & Mpingu \\
\hline $\begin{array}{l}\text { Population density } \\
\quad\left(\text { persons } \mathrm{km}^{-2}\right)^{1}\end{array}$ & 610 & 310 & 190 & 135 & 100 & 325 \\
\hline $\begin{array}{l}\text { Total rainfall } \\
\left(\mathrm{mm} \text { year }^{-1}\right)^{2}\end{array}$ & 1380 & 1148 & 1208 & 969 & 934 & 1041 \\
\hline $\begin{array}{l}\text { Rainfall } \\
\text { seasonality }^{3}\end{array}$ & $\begin{array}{l}\text { Single wet season } \\
\text { regime, bimodal }\end{array}$ & $\begin{array}{l}\text { Single wet season } \\
\text { regime, uni- } \\
\text { bimodal }\end{array}$ & $\begin{array}{l}\text { Single wet season } \\
\text { regime, bimodal }\end{array}$ & $\begin{array}{l}\text { Single wet season } \\
\text { regime, unimodal }\end{array}$ & $\begin{array}{l}\text { Single wet season } \\
\text { regime, unimodal }\end{array}$ & $\begin{array}{l}\text { Single wet season } \\
\text { regime, unimodal }\end{array}$ \\
\hline $\begin{array}{l}\text { Farming systems } \\
\text { (crop) }\end{array}$ & $\begin{array}{l}\text { Maize and tef as } \\
\text { main cereals, } \\
\text { haricot bean, } \\
\text { faba bean and } \\
\text { vegetables }\end{array}$ & $\begin{array}{l}\text { Maize dominant, } \\
\text { bush bean, } \\
\text { vegetable } \\
\text { production in the } \\
\text { valleys }\end{array}$ & $\begin{array}{l}\text { Highland banana } \\
\text { / coffee, with } \\
\text { many food } \\
\text { crops, maize, } \\
\text { bean, cassava }\end{array}$ & $\begin{array}{l}\text { Cereal-legume } \\
\text { based, } \\
\text { maize with cowpea, } \\
\text { groundnut and } \\
\text { soyabean }\end{array}$ & $\begin{array}{l}\text { Cotton as cash } \\
\text { crop, sorghum } \\
\text { and millet with } \\
\text { maize production } \\
\text { increasing }\end{array}$ & $\begin{array}{l}\text { Maize dominant, } \\
\text { groundnut and } \\
\text { soybean as cash } \\
\text { crops }\end{array}$ \\
\hline
\end{tabular}

${ }^{1}$ (Center for International Earth Science Information Network-CIESIN); NASA Socioeconomic Data and Applications Center (SEDAC). https://doi.org/10.7927/H49C6VHW

${ }^{2}$ CHIRPS Rainfall Data: 2010-2019 yearly average (Funk et al., 2015)

${ }^{3}$ Continental classification of rainfall seasonality regimes in Africa (Herrmann \& Mohr, 2011)

\subsection{RHoMIS survey data}

Six contrasting examples of farming systems across six countries were selected from the Rural Household Multiple
Indicator Survey (RHoMIS) database (van Wijk et al., 2020, Table 1). Data were collected in the framework of different projects that made use of the RHoMIS survey tool: the "Grass To Cash" (GTC) project in Ethiopia (2019), the
Fig. 1 Spatial distribution of the household level data. LSMSISA households (World Bank, 2020) georeferenced at the enumeration area level (Table S1) are represented by black dots. RuLIS households (FAO, 2018) georeferenced at the regional level are represented by grey circles proportional to the number households surveyed. The six sites with contrasting farming systems where we performed in-depth food security and income analyses using RHoMIS households (van Wijk et al., 2020) are represented by yellow diamonds. Agroecological zones were retrieved from IFPRI (2015) and are described in Table $\mathrm{S} 1$

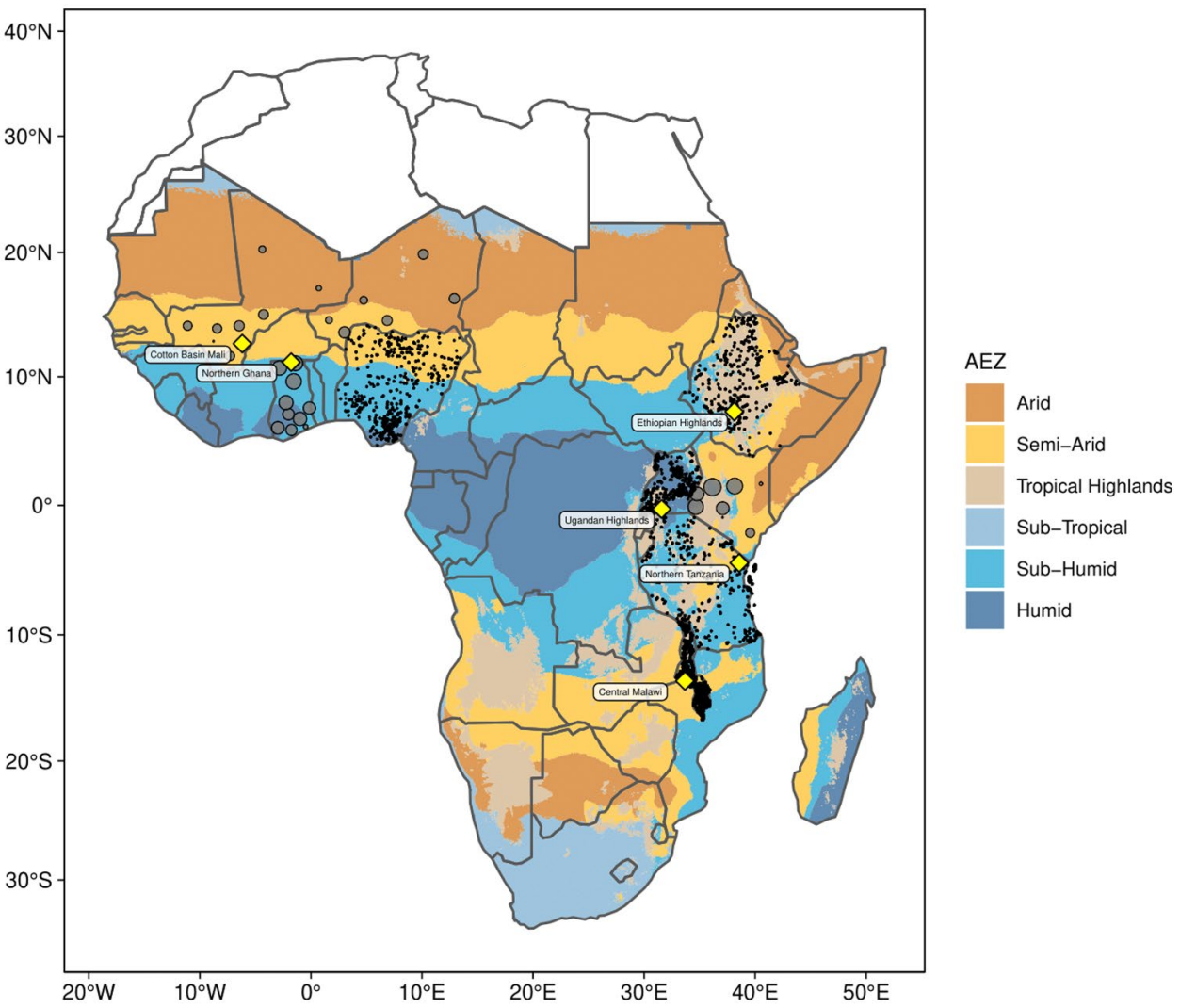


Climate Change, Agriculture and Food Security (CCAFS) programme in Tanzania (2015) and Uganda (2017), the Tree Aid project in Ghana (2018), the project "Developing smallholder strategies for fall armyworm management in southern Africa: Examining the effectiveness of ecological control options" (FAW) in Malawi (2019), and the project "Pathways to agro-ecological intensification in croplivestock farming systems in southern Mali" from the Collaborative Crop Research Programme (CCRP) of the McKnight Foundation (2018). The RHoMIS tool consists of reusable questionnaire modules for rural household surveys, and software infrastructure designed for rapid data collection and processing of standardised indicators (Hammond et al., 2017). Such indicators are intended to facilitate the analysis of farm management, crop and livestock production, as well as household income, welfare, and livelihood. The RHoMIS tools are open source and supported by a community of practice aiming to encourage standardisation in the collection of rural household data (see https://www.rhomis.org). For each location, we extracted data from a single research project, selecting the most recent one in case multiple surveys were performed. A total of 1024 households were selected, situated within a $30 \mathrm{~km}$ radius from the centre of each study area.

Study site environments were characterized with a number of geospatial layers describing annual rainfall average, rainfall seasonality and population density. Long term rainfall averages $\left(\mathrm{mm}\right.$ year $\left.{ }^{-1}\right)$ were computed with monthly rainfall estimates at $5 \mathrm{~km}$ resolution from the Climate Hazards Group InfraRed Precipitation with Station (CHIRPS) data (Funk et al., 2015), and averaged over the 2010-2019 period. Rainfall seasonality regime classification, defined as the number of wet seasons per year (single, multiple) and the number of rainfall peak per wet season (unimodal, bimodal) was extracted from the Continental-Scale Classification of Rainfall Seasonality Regimes in Africa Based on Gridded Precipitation and Land Surface Temperature Products (Herrmann \& Mohr, 2011) at a $30 \mathrm{~km}$ resolution. Estimates of population density (persons $\mathrm{km}^{-2}$ ) corresponding to the survey year were extracted from the WorldPop unconstrained top-down population count product at $1 \mathrm{~km}$ resolution, adjusted to match United Nations population estimates (Lloyd et al., 2017). Geospatial data were extracted at the household level and averaged over the study sites.

\subsection{Data processing}

Farm household wealth and food security indicators were retrieved and adapted from the RHoMIS database to explore household diversity among the study sites (Table 2). Data were thoroughly checked and households with missing values or exceeding the $99^{\text {th }}$ percentile threshold in key indicators were excluded from further analysis. A total of 873 households were retained for the analysis (Table S3).

\subsubsection{Demographics}

Household composition was reported as the number of household members per gender (male or female) and age group (4-10, 11-24, 25-50, and over 50 years old). Food security indicators were calculated per day and household member, expressed per male adult equivalent (MAE) to account for age and gender differences in energy requirements (van Wijk et al., 2020; Weisell \& Dop, 2012) and allow the direct comparison of energy intake of households of different sizes and compositions. Income indicators, also calculated per day and per household member, were expressed per adult equivalent, following the OECD equivalent scale (Chanfreau \& Burchardt, 2008) to adjust household income to differences in resources needed by single adults, additional adults in the household, and children.

\subsubsection{Income}

Household income and production value were expressed in 2010 equivalent US dollars converted from local currency using purchasing power parity (ppp) exchange rates per adult equivalent per day (USD ppp $\mathrm{AE}^{-1} \mathrm{day}^{-1}$ ). The total income indicator was calculated as the sum of offfarm income and on-farm income generated from crop and livestock sales. Farm product sales were calculated from local prices, retrieved at the time of the survey (Hammond et al., 2017). In addition, the total value of agricultural household activities, expressed in USD ppp $\mathrm{AE}^{-1} \mathrm{day}^{-1}$, was calculated by adding the value of crop and livestock products consumed. Household income indicators were compared to the USD 1.9 person $^{-1}$ day $^{-1}$ absolute poverty line and the living income reference values (van de Ven et al., 2020a, 2020b). The living income benchmark is an estimate of the income required to meet the basic human rights for a decent living, namely food, shelter, health and education with a small margin for unseen costs, specific to that country or region.

\subsubsection{Production value}

Detailed information on specific cultivated crops allowed us to analyse household production on a per crop-basis and explore the diversity of cropping systems between and within the selected sites (Table 3). For each household $\times$ crop 
Table 2 Household indicators, and units, analysed in this study

\begin{tabular}{|c|c|c|}
\hline Topic & Indicator & Unit \\
\hline Household demographics & Household size & $\begin{array}{l}\text { Adult Equivalent (AE) or } \\
\text { Male Adult Equivalent (MAE) }\end{array}$ \\
\hline \multirow[t]{6}{*}{ Household income } & Land cultivated & ha \\
\hline & Livestock holdings & TLU \\
\hline & Total income & USD ppp $\mathrm{AE}^{-1}$ day $^{-1}$ \\
\hline & Off-farm income & USD ppp $\mathrm{AE}^{-1}$ day $^{-1}$ \\
\hline & On-farm income & USD ppp $\mathrm{AE}^{-1}$ day $^{-1}$ \\
\hline & Total value of activities ${ }^{1}$ & USD ppp $\mathrm{AE}^{-1} \mathrm{day}^{-1}$ \\
\hline \multirow[t]{6}{*}{ Household production } & Total value of livestock production & USD ppp $\mathrm{AE}^{-1}$ day $^{-1}$ \\
\hline & Value of livestock prod. sold & USD ppp $\mathrm{AE}^{-1}$ day $^{-1}$ \\
\hline & Value of livestock prod. consumed & USD ppp $\mathrm{AE}^{-1}$ day $^{-1}$ \\
\hline & Total value of farm production & USD ppp $\mathrm{AE}^{-1}$ day $^{-1}$ \\
\hline & Value of crop prod. sold & USD ppp $\mathrm{AE}^{-1}$ day $^{-1}$ \\
\hline & Value of crop prod. consumed & USD ppp $\mathrm{AE}^{-1} \mathrm{day}^{-1}$ \\
\hline \multirow[t]{2}{*}{ Food security } & Food availability & $\mathrm{kcal} \mathrm{MAE}^{-1} \mathrm{day}^{-1}$ \\
\hline & Food self-sufficiency & $\mathrm{kcal} \mathrm{MAE}^{-1}$ day $^{-1}$ \\
\hline
\end{tabular}

${ }^{1}$ The total value of activities represents the sum of off-farm incomes, on-farm incomes from sales, and the values of consumed farm products

ppp purchasing power parity, $T L U$ tropical livestock unit combination, the harvested, sold and consumed quantity, the cultivated area, and the generated income from sales were systematically reported. Households with reported harvested quantities but missing information on the share that was consumed and the share that was sold were discarded from the analysis. From these data, the total value of crop production expressed in USD ppp $\mathrm{AE}^{-1}$ day $^{-1}$ was calculated. For each crop produced in a household, the value of the harvest was estimated using local crop prices and expressed in USD ppp. Crops were assigned to a broader crop group for the graphical representation: various fruits and vegetables, legume crops, various cereals and non-edible cash crops, with the exception of major staple crops: maize, rice, cassava and banana.

\subsubsection{Food security}

Food availability (FA) and food self-sufficiency (FSS) indicators, expressed in kilocalories per male adult equivalent per day (kcal. MAE ${ }^{-1} \mathrm{day}^{-1}$ ) were used to assess household food security. Food availability (Eq. 1) represents the amount of energy that can be generated from on-farm consumption (Eq. 1) of food crops and livestock products, plus the potential food that could be purchased from income earned through off-farm (such as paid employment, remittances, etc.) and on-farm activities such as sales (Frelat et al., 2016; Hammond et al., 2017). The amount of energy that could be generated from purchases was expressed in maize energy equivalent $\left(\mathrm{M}_{\mathrm{eq}}\right)$. The value of livestock products consumed was also expressed in $\mathrm{M}_{\mathrm{eq}}$. Food availability was calculated at the household level, for $i$ staple crops produced on farm $j$, with $k$ the respective crop energy content $\left(\mathrm{kcal} \mathrm{kg}^{-1}\right)$.

$F A_{j}=\frac{\sum_{i} \text { Consumed }_{i j} \times k_{i}+M_{e q(\text { livestock consumed }) j}+M_{\text {eq (purchased }) j}}{M A E_{j}}$

On the other hand, food self-sufficiency (Eq. 2) represents the amount of energy available if all crop and livestock products produced on-farm would be consumed by the household, ignoring food that could be purchased by off-farm income. Again, the value of livestock products consumed by the household was converted into maize energy equivalents.

$\mathrm{FSS}_{j}=\frac{\sum_{i} \text { Produced }_{i j} \times k_{i}+M_{\text {eq(livestock produced }) j}}{M A E_{j}}$

Household food availability and food self-sufficiency were compared to the $2500 \mathrm{kcal} \mathrm{day}^{-1}$ male adult requirement reference value (Holden et al., 2001). The amount of energy from the quantity of maize that could be purchased, or equivalent to the livestock product value, was estimated using local maize prices at the time of the study. The dietary diversity score, expressed in number of unique food groups consumed, was used as indicator for nutrition security (van Wijk et al., 2020). 
Table 3 Median values of the main household indicators for the selected farming systems from the RHoMIS database (van Wijk et al., 2020)

\begin{tabular}{|c|c|c|c|c|c|c|}
\hline & $\begin{array}{l}\text { Ethiopian } \\
\text { Highlands }\end{array}$ & $\begin{array}{l}\text { Northern } \\
\text { Tanzania }\end{array}$ & $\begin{array}{l}\text { Ugandan } \\
\text { Highlands }\end{array}$ & Northern Ghana & Cotton Basin Mali & Central Malawi \\
\hline \multicolumn{7}{|l|}{ Farm characteristics } \\
\hline Household size (AE) & 3.6 & 3.6 & 4.6 & 4.8 & 11.9 & 3.2 \\
\hline Land owned (ha) & - & - & 1.6 & 2.0 & 16.5 & 0.6 \\
\hline Land cultivated (ha) & 0.5 & 0.8 & 1.6 & 1.6 & 10 & 0.4 \\
\hline Livestock (TLU) & 1.50 & 0.80 & 0.87 & 1.20 & 6.29 & 0.02 \\
\hline \multicolumn{7}{|l|}{ Food security indicators } \\
\hline Food Self Sufficiency (kcal MAE ${ }^{-1}$ day $^{-1}$ ) & 713 & 868 & 2646 & 813 & 6310 & 1142 \\
\hline Households above $2500 \mathrm{kcal} \mathrm{MAE}^{-1}$ day $^{-1}(\%)$ & 22 & 18 & 51 & 11 & 97 & 25 \\
\hline $\begin{array}{l}\text { Food availability }\left(\mathrm{kcal} \mathrm{MAE}^{-1} \mathrm{day}^{-1}\right) \\
\text { Households above } 2500 \mathrm{kcal} \mathrm{MAE}^{-1} \mathrm{day}^{-1}(\%)\end{array}$ & $\begin{array}{l}839 \\
29\end{array}$ & $\begin{array}{l}1432 \\
32\end{array}$ & $\begin{array}{l}4621 \\
75\end{array}$ & $\begin{array}{l}695 \\
10\end{array}$ & $\begin{array}{l}11,629 \\
98\end{array}$ & $\begin{array}{l}1197 \\
29\end{array}$ \\
\hline \multicolumn{7}{|l|}{ Income indicators } \\
\hline $\begin{array}{l}\text { Total household income }{ }^{1} \text { (USD ppp } \\
\mathrm{AE}^{-1} \text { day }^{-1} \text { ) }\end{array}$ & 0.06 & 0.11 & 0.56 & 0.02 & 1.20 & 0.00 \\
\hline Household above poverty $\operatorname{line}^{3}(\%)$ & 5 & 1 & 15 & 1 & 22 & 6 \\
\hline Households above living income ${ }^{4}(\%)$ & 0 & 0 & 6 & 0 & 30 & 1 \\
\hline $\begin{array}{l}\text { Total crop production value }{ }^{2} \text { (USD ppp } \\
\mathrm{AE}^{-1} \text { day }^{-1} \text { ) }\end{array}$ & 0.24 & 0.16 & 1.85 & 0.31 & 1.71 & 0.23 \\
\hline Household above poverty $\operatorname{line}^{3}(\%)$ & 1 & 1 & 49 & 1 & 44 & 1 \\
\hline Households above living income ${ }^{4}(\%)$ & 0 & 0 & 16 & 0 & 48 & 0 \\
\hline \multicolumn{7}{|l|}{ Other indicators } \\
\hline Dietary diversity score (good - bad season) & $5-2$ & $1-1$ & $8-4$ & $6-4$ & $7.5-6$ & $6-3$ \\
\hline Progress out of Poverty Index (\%) & 31.6 & 31.2 & 16.7 & 10.9 & 95.9 & - \\
\hline
\end{tabular}

${ }^{1}$ Total household income excludes farm production that is directly consumed by the household

${ }^{2}$ Total crop production value includes production consumed by the household and produce sold

${ }^{3}$ Absolute poverty line is USD 1.9 person $^{-1}$ day $^{-1}$

${ }^{4}$ Living income for the Ethiopian Highlands: USD 3.6 person $^{-1}$ day $^{-1}$, Northern Tanzania: USD 4.04 person $^{-1}$ day $^{-1}$, Ugandan Highlands: USD 3.82 person $^{-1}$ day $^{-1}$, Northern Ghana: USD 2.62 person $^{-1}$ day $^{-1}$, Cotton Basin Mali: USD 1.73 person $^{-1}$ day $^{-1}$, and Central Malawi USD 4.00 person $^{-1}$ day $^{-1}$ (van de Ven et al., 2020a, 2020b)

\subsection{Food security scenarios}

A scenario analysis was conducted to explore the effect of narrowing yield gaps on FA, FSS, and total income. For this purpose, two target yield levels were used to estimate yield gap closure for each crop in each site (Table 4). First, the highest farmers' yield $\left(\mathrm{Y}_{\mathrm{HF}}\right)$ was considered as a locally realistic benchmark that refers to the 90th percentile of Ya across a population of farms (Silva et al., 2017; van Ittersum et al., 2013). $\mathrm{Y}_{\mathrm{HF}}$ was thus estimated from the distribution of Ya observed in the household survey data for each crop in each site. Second, the 'locally attainable yield' $\left(\mathrm{Y}_{\mathrm{ATT}}\right)$ refers to the maximum crop yield observed in on-farm experiments under optimal management and input application but without irrigation (cf. Tittonell \& Giller, 2013) which captures possible crop yields greater than $Y_{H F}$ in each site. $\mathrm{Y}_{\text {ATT }}$ values were obtained for each crop $\times$ site combination based on expert knowledge from local agronomists (Table 4). The actual yield (Ya) was obtained from self-reported data on production and area recorded in the household survey and yield gap closure was computed as the ratio between the Ya and each of the target yield levels (i.e., $\mathrm{Y}_{\mathrm{HF}}$ and $\mathrm{Y}_{\mathrm{ATT}}$ ). The scenario analysis thus consisted of a re-estimation of the FA, FSS, and total income indicators using the crop- and site-specific $\mathrm{Y}_{\mathrm{HF}}$ and $\mathrm{Y}_{\mathrm{ATT}}$ yield levels instead of Ya.

For simplicity, the scenario analysis considered only the five most frequently cultivated crops grown by the households in each site (Table 4) and the contribution of other less-frequently cultivated crops were ignored in the in the scenario analysis. The share of the produced quantities dedicated by the households for consumption or sales were kept as per the baseline situation (i.e., as observed in the household survey data).

FA, FSS and total income were calculated according to the methods described in Section 2.3 but considering the following scenarios: 1) a baseline situation using Ya of the selected crops, 2) a scenario in which the yield of 


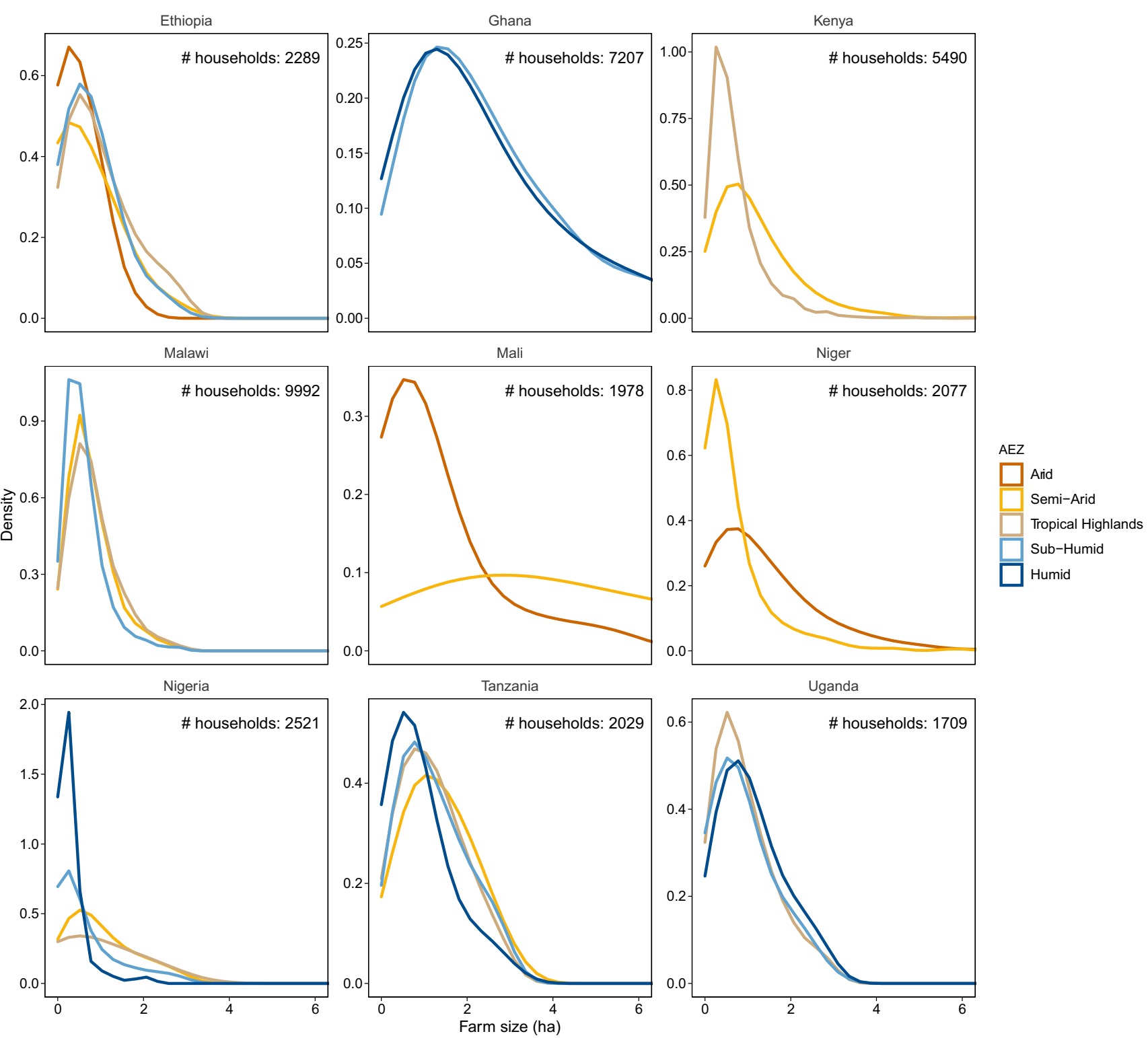

Fig. 2 Density distributions of farm size across different agroecological zones for selected countries in sub-Saharan Africa. Agroecological zones were retrieved from IFPRI (2015) and are described in Table S1. Farm sizes were retrieved from the LSMS-ISA (World
Bank, 2020) data library for Ethiopia (2011-2012), Malawi (20102011), Nigeria (2013), Tanzania (2010-2011), and Uganda (20102011) and from the RuLIS (FAO, 2018) data library for Ghana (2012-2013), Kenya (2005-2006), Mali (2014), and Niger (2014) the selected crops reaches $50 \%$ of $\mathrm{Y}_{\mathrm{HF}}, 3$ ) a scenario in which the yield of the selected crops reaches $\mathrm{Y}_{\mathrm{HF}}$ and, 4) a scenario in which the yield of the selected crops reaches $\mathrm{Y}_{\text {ATT }}$. For each scenario and indicator, the proportion of households meeting the food security standard of $2500 \mathrm{kcal} \mathrm{day}^{-1}$ per male adult equivalent (MAE) and the proportion of households meeting the living income (van de Ven et al., 2020a) and the USD 1.9 person $^{-1}$ day $^{-1}$ poverty line was calculated.

\subsection{Population pressure on croplands}

The current and future population pressure on agricultural land was assessed by determining the number of people per ha of cropland for the current (2015) population and future (2050) population projections with and without cropland expansion. The current cropland area was derived from FAOSTAT (FAO, 2020) and the projected number of inhabitants per country in 2050 were derived from the United 
Nations (2017) World Population Prospects, 2017 revision. Suitable areas for agriculture were derived from datasets as used and described in Chamberlin et al. (2014) and refer to the potentially available cropland under a "high management" scenario.

\section{Results and discussion}

\subsection{Farm size in relation to agroecological zones}

The analysis of farm size distributions across different agroecological zones (Fig. 2) was based on large scale, nationally representative household surveys. The very small farm size across the board is striking with the vast majority of farms being smaller than 1 ha. Farms tend to be larger in drier agroecological zones (cf. Mali with countries in East Africa), though this is not always the case. In Nigeria farm sizes are much smaller in the humid climates of the Niger delta where production is possible year-round, than in the north of the country which extends into the drier SudanoSahelian zone with only one cropping season each year. A similar pattern is seen for Tanzania, with much smaller farm sizes in the more humid climates where two seasons a year are possible, than in drier regions with unimodal rainfall.

The analysis confirms earlier findings regarding the relation between farm size and agro-ecological potential, and the economic viability of small farms (Hengsdijk et al., 2014; van Wijk et al., 2019). The small farm sizes limit farmers' ability to become food secure and rise out of poverty. In our analysis the vast majority of farms are very small, less than 1 ha with very few exceeding 3 ha in size. In most cases these farms support a household of 5-8 people (Table 3). The area of land available to a household for farming - the farm size - is critical in determining the viability of the farm (Harris, 2019; Harris \& Orr, 2013). Agroecological potential in terms of climate and soils clearly is very important in determining population density and farm size, but it is not the only factor. Local settlement histories are also important. For example, Malawi has only one rainy season per year, but a very high population density and small farms. A long history of insecurity and lack of infrastructure in neighbouring areas in Mozambique led to a concentration of people in southern Malawi, which was relatively safer and better developed (McCracken, 2012). In Ethiopia there is a tendency of smaller farms in the drier highlands of the north than in the more humid climates towards the south and west of the country, although the median farm size is well below 1 ha across all zones. Also here, settlement history partly explains why this pattern is opposite of what might be expected based on agroecological potential (Fig. 2).

Our results differ strongly from the analysis of Samberg et al. (2016) who indicate an equivalent proportion of farm land holdings in sub-Saharan Africa fall in a category of $2-5$ ha as in the category smaller than 2 ha. This is presumably explained by the method they employed where grazing land and cropland were both included as agricultural land which was distributed among the number of farming households in each administrative district. Our results also show that using a standard, area-based farm size definition (e.g. smaller than $2 \mathrm{ha}$ ) is not a robust way to define a smallholder farm. In dry areas a substantial proportion of such farms is larger than 2 ha, while they are clearly small farms in economic terms. In high agroecological potential areas with high population densities, a farm of close to 2 ha can already be considered to be a large farm, with the majority of smallholder farms having an area less than 1 ha.

The household data used relies on farmers' own estimates of their land-holdings. Farmer-reporting of farm sizes may introduce systematic bias, but given that households with smaller farm sizes tend to overestimate their holdings, and those with larger farms tend to underestimate their holdings (Carletto et al., 2013), such errors would only tend to support the general conclusion that farms across sub-Saharan Africa are generally very small. Larger 'commercial' farms tend not to be captured in rural household surveys and only show up in agricultural census data (Lowder et al., 2016). Such farms represent a small fraction of the total number of farms although they may occupy a large proportion of the land. We discuss the role of larger farms that may be missed in such surveys below.

\subsection{Differences in food self-sufficiency, poverty and living income among farming systems}

To gain deeper insights into the diversity and current status of farming households we delve into the RHoMIS database and specifically selected farming systems where we can build on detailed background research to aid interpretation. These locations are not nationally-representative, but serve to illustrate the situation in the specific agroecologies from which they are drawn. We examine three examples from the East African highlands; the southern highlands of Ethiopia, South-west Uganda and the West Usambara Mountains of Tanzania. The highlands of East Africa have long been densely-settled and under permanent agriculture. The fertile soils resulting from volcanic rejuvenation of the landscape in the East African Rift, coupled with welldistributed rainfall that allows two cropping seasons each year, led to sedentary agriculture already before the $19^{\text {th }}$ Century (e.g. Crowley \& Carter, 2000). In the southern highlands of Ethiopia, maize and tef (Eragrostis tef) are the main cereals together with common bean, faba bean and a range of vegetables. The West Usambara Mountains, were described as being denuded and degraded hillsides due to 
dense populations already at the end of $19^{\text {th }}$ Century (Huijzendveld, 1997). Since then the population increased sixfold. Maize and beans are the major food crops on steep hillsides, and some households cultivate vegetables in the valley bottom with irrigation. Since the 1980 s, vegetable production has become heavily commercialised with trucks leaving in the night for the markets of Dar-es-Salaam, some $400 \mathrm{~km}$ to the south. The perennial-based cropping systems of South-west Uganda are dominated by East African highland banana as major staple crop and coffee as cash crop, as well as annual crops such as maize, beans and cassava. Highland banana has increasingly become a cash-crop traded to feed the urban population of Kampala. In West Africa, we zoom in on the Cotton Basin of the Cercle de Koutiala in southern Mali. Major food crops are sorghum and millet, often grown in rotation or intercropped with cowpea and groundnuts as legumes. Cotton and also maize are important cash crops, and there is strong integration with livestock for tillage and manure. A contrasting location is the Upper East region of Ghana. Although similar in terms of agroecological zone and main food crops, the major cash crops are legumes; groundnut and soyabean. In southern Africa we highlight the Lilongwe Plain in Central Malawi, a location close to the capital city. Maize is the predominant staple crop, with groundnut grown as a cash crop.

Our detailed analyses of farming systems in divergent agroecologies reveal a rather stark reality. Only $10 \%$ of households in Navrongo, northern Ghana, $18 \%$ in Lushoto, northern Tanzania and $22 \%$ in Sodo, Ethiopia produce enough food to feed the family (i.e. lie above the Food Selfsufficiency indicator threshold of $2500 \mathrm{kcal} \mathrm{MAE}^{-1}$ day $^{-1}$; Table 3; Fig. 3). By contrast, some $97 \%$ of households in the Cotton Basin, Mali appear to be food self-sufficient. The farm sizes captured in the RHoMIS survey in Mali (Table 3) are substantially larger than those observed in Fig. 2. This appears to be due to a different definition of a farm household applied in RHoMIS survey which considered all people living within one farm compound, that is the extended farm family, whereas most surveys consider the nuclear family.

In all locations we see enormous variation among the households but a very similar shape of distribution, with few better-off households - at the right side of the graph - and a long tail to the left, which represent the poorest households (Fig. 3). All locations are characterised by strong social differentiation. Since many farming households in SSA are net consumers of food, it is obvious that the proportion of food secure households rises if we add the caloric (maize) equivalent of all household income (agricultural sales and off-farm income) to the caloric value of the household's self-consumed production (Fig. 3b). Yet, this Food Availability indicator also suggests a problem of data and analysis, as large numbers of households remain below the threshold of $2500 \mathrm{kcal} \mathrm{MAE}^{-1} \mathrm{day}^{-1}$ when all major sources of income and food are considered. While hunger is undoubtedly a recurrent feature of rural life in these areas, it is likely that household surveys do not adequately capture all caloric sources of these farming households.

The most food secure regions in terms of energy, such as the Cotton Basin, Mali and the Ugandan Highlands are also most nutrition secure. In Northern Tanzania, with a low food self-sufficiency, the dietary diversity score falls as low as 1 . The dietary diversity score in bad seasons is substantially worse than in good seasons, illustrating the importance of seasonality in food and nutrition security assessment (Table 3). If all income is converted into calories (the Food Availability indicator), the proportion of food secure households rises, but in none of the locations are all households food secure, and in the worst case (Northern Ghana) only $11 \%$ of the households are above the threshold (Table 3; Fig. 3).

To evaluate variability in household incomes we used two indicators - the total value of all crops produced on farm, including cash crops (Fig. 3c), and the total household net income which includes income earned off-farm and subtracts production costs (Fig. 3d). Not surprisingly, these indicators show similar wide differences among households within each location. The distribution curves are similar in shape to the food self-sufficiency and the food availability indicators, as food crops account for a large share of what is produced on farm. We compare these income indicators with two threshold values: the absolute poverty line of USD 1.9 person $^{-1}$ day $^{-1}$ and the Living Income indicator which has been derived independently for each country (van de Ven et al., 2020b). In contrast to the other countries, the Living Income benchmark in Mali was below the poverty line. Although surprising, it can be explained firstly by the fact that the poverty line is based on average statistics across the 15 poorest countries, with Mali amongst them. Secondly, the typically large Malian households result in economies of scale, especially for housing costs. The proportion of households that earn an income above each of these thresholds is presented in Table 3. The contribution of each of the five most important crops in each location (Table 4) confirms the relative importance of different cash crops to household incomes across the locations: highland banana in Uganda, cotton in Mali and legumes (groundnut and soyabean) in Malawi (Fig. 3c). The results highlight the prevalence of food insecurity and poverty: a large majority of the households fall below the poverty line and do not achieve a living income.

As described by Giller et al. (2021), we see the outcomes of a mixture of pathways of intensification, marginalization and extensification. The locations in the East African highlands have a more favourable agroecology in terms of inherently fertile soils and bimodal rainfall distribution which allows at least two crops a year, yet the Ethiopia and Tanzania locations are among those with the strongest incidence of 
Fig. 3 Distributions of key indicators for households of selected farming systems of sub-Saharan Africa from the RHoMIS database (van Wijk et al., 2020). Food Selfsufficiency ( $\mathrm{kcal} \mathrm{MAE}^{-1} \mathrm{day}^{-1}$ ) is the total food produced on farm converted to calories per male adult equivalent (MAE) per day. The Food Availability indicator is calculated in a similar way but all income is converted into calories (Frelat et al., 2016). Food availability and self-sufficiency are represented against the $2500 \mathrm{kcal} \mathrm{day}^{-1}$ male adult requirement reference value (Holden et al., 2001). Income is expressed as USD ppp equivalent for 2018 per adult equivalent per day, against thresholds of the absolute poverty line (USD 1.9 individual $^{-1}$ day $^{-1}$, red dashed line) and the Living Income (USD ppp $\mathrm{AE}^{-1}$ day $^{-1}$, black dashed line)
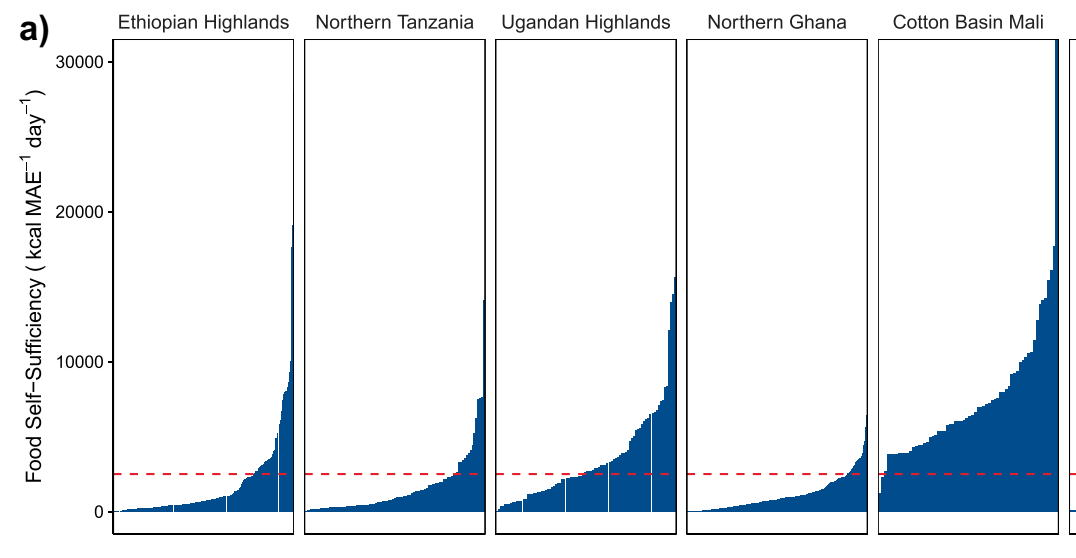

Central Malawi

b)
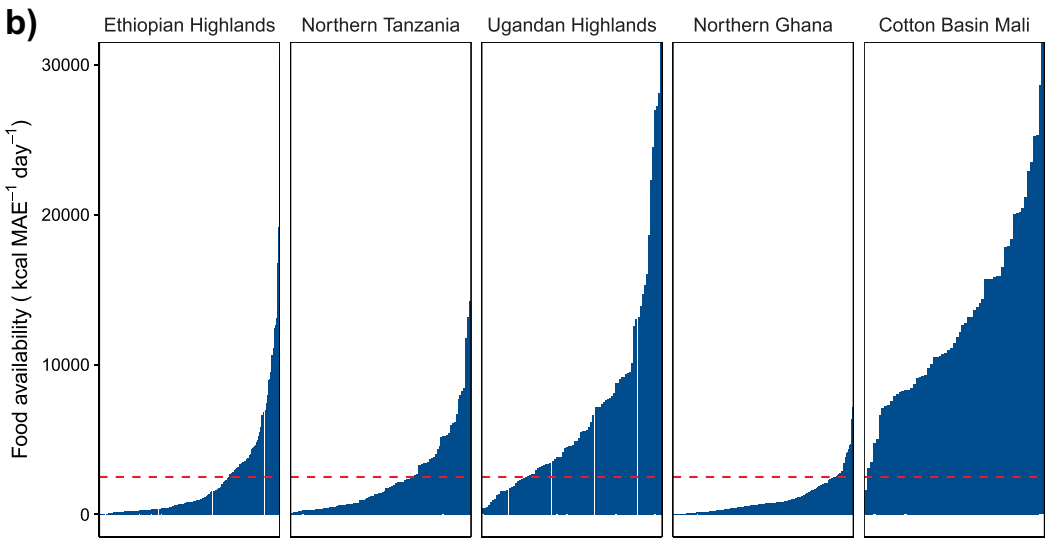

Central Malawi

c)

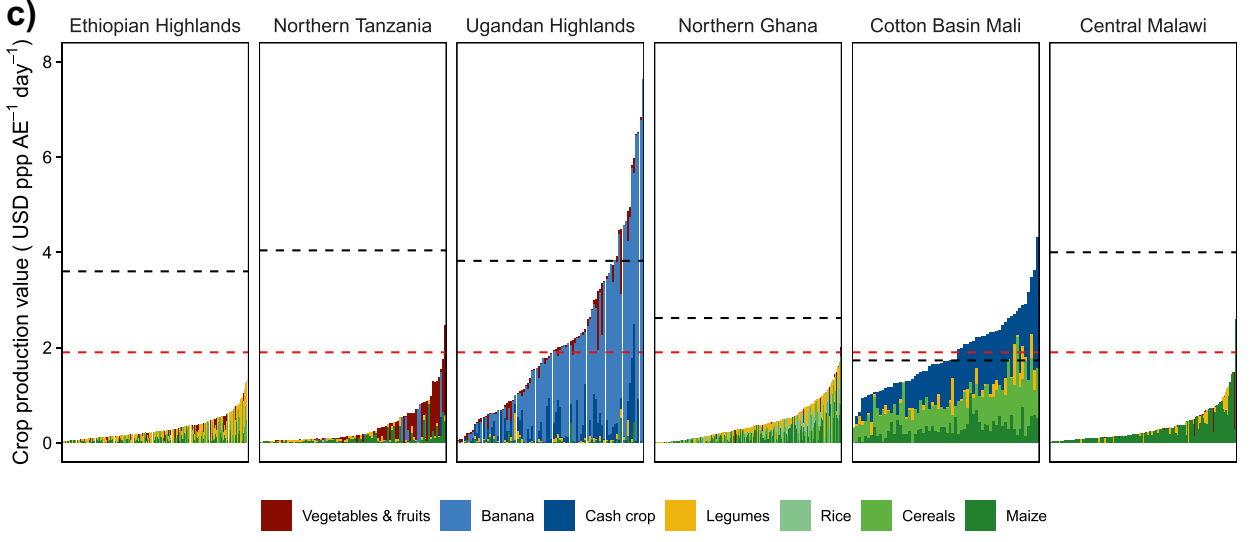

d)
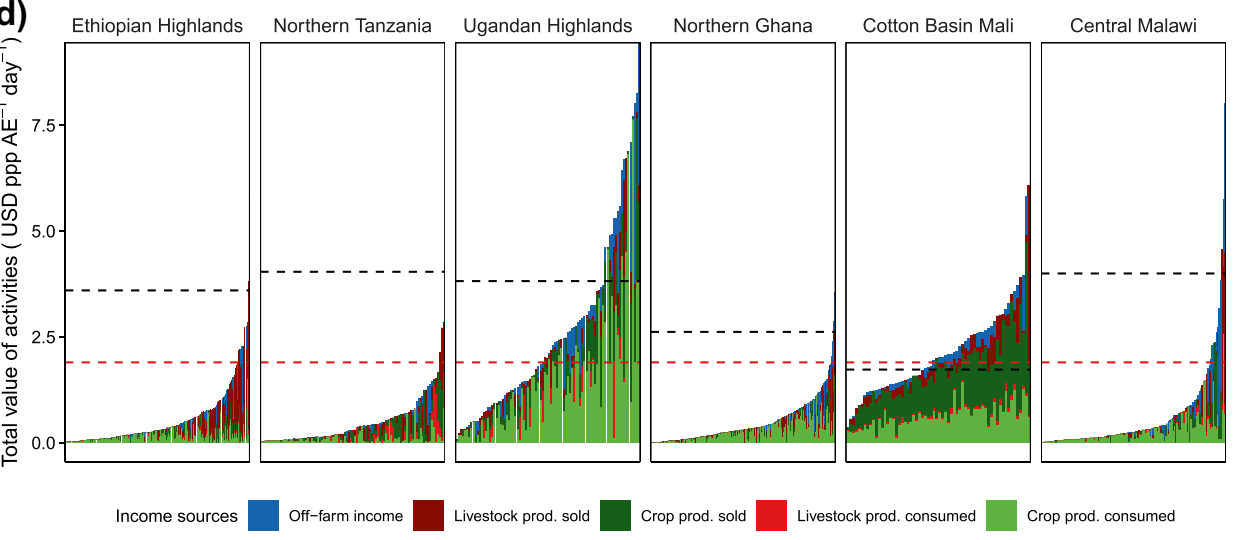
Fig. 4 Cultivated area per farm for households of selected farming systems of sub-Saharan Africa from the RHoMIS database (van Wijk et al., 2020). The households are divided into three classes for a) Food self-sufficiency (FSS): those that achieve FSS ( $>2500 \mathrm{kcal}$ $\mathrm{MAE}^{-1}$ day $^{-1}$ ), those with 1250-2500 kcal MAE ${ }^{-1} \mathrm{day}^{-1}$, and those below $1250 \mathrm{kcal}$ $\mathrm{MAE}^{-1}$ day $^{-1}$; b) those who achieve a Living Income, those who have less than a Living Income but above the absolute poverty line USD ppp 1.9 indivudual ${ }^{-1}$ day $^{-1}$, and those with an income less than the absolute poverty line. Note that for Mali, the living income is slightly less than the poverty line
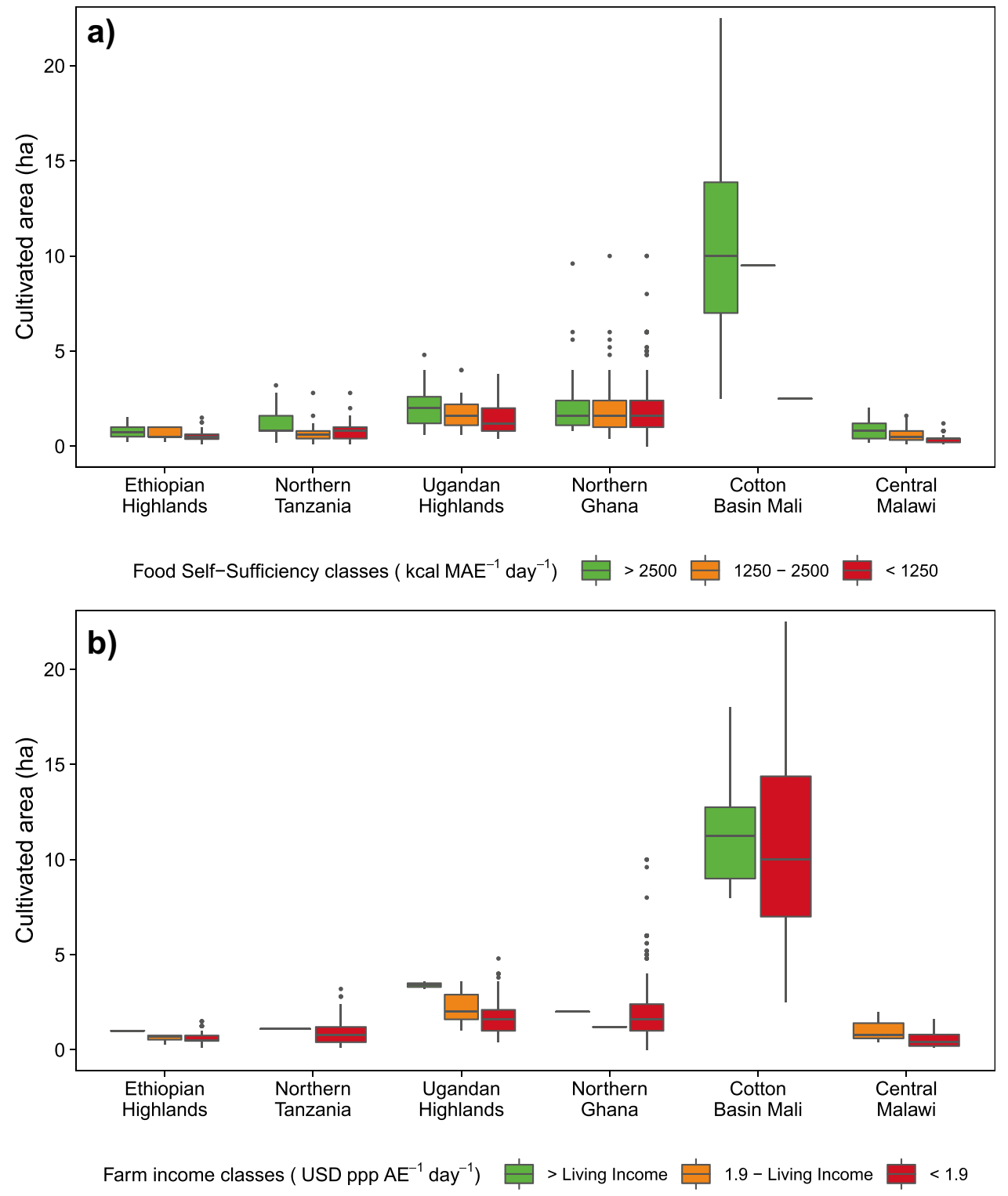

food insecurity and poverty. In these locations, population densities are high ( $>300$ persons $\mathrm{km}^{-2}$ ) and farms extremely small, whereas the population is less dense in South-west Uganda (192 persons $\mathrm{km}^{-2}$ ) with larger farms (Table 3). This contrast is clearly reflected in more favourable indicators in South-west Uganda with $51 \%$ food self-sufficient households and $15 \%$ above the poverty line, compared to alarmingly low percentages of not more than $22 \%$ and $5 \%$ of the population food self-sufficient and above the poverty line respectively in Ethiopia and Tanzania. Perhaps surprisingly, almost all households are food self-sufficient (97\%) and almost half of the households achieve a living income (48\%) under less favourable agroecological conditions (drier climate and poorer soils) in the Cotton Basin of Mali. Cotton is very important as a cash crop in Mali, contributing strongly to income. By contrast, in a very similar agroecology in northern Ghana, but with a greater population density (135 vs 100 persons $\mathrm{km}^{-2}$ in Mali), and relatively little income from cash crops, few households are food self-sufficient (10\%) and only $1 \%$ are above the poverty line. In Central Malawi, the other location with and a single growing season, population density is much higher ( 325 persons $\mathrm{km}^{-2}$ ) and the median farm size much smaller ( 0.4 ha). Here $25 \%$ of the households achieve food self-sufficiency, but few households are above the poverty line (6\%) and only $1 \%$ earn a living income.

Farm size is a major determinant of food self-sufficiency and farm income (Fig. 4), both across and within locations. Within a given agroecology more of the households fall into the 'better-off' classes in terms of food self-sufficiency or income where farm sizes are larger. For instance, there are more better-off households which achieve food self-sufficiency or achieve a living income in the Uganda location where farms 
are larger location than in the Tanzania or Ethiopia locations where farms are very small. Similarly, a larger proportion of the households are food self-sufficient or earn a living income from farming in Mali than in northern Ghana. Within each individual location the farms that are better-off in terms of food self-sufficiency or income are comparatively larger.

\subsection{Impacts of closing yield gaps to locally-attainable yields}

The scenarios reveal that narrowing yield gaps increases the proportion of households who are food self-sufficient or food secure across all locations considerably (Fig. 5). Yet even with the largest possible increases in yield, only in three out of the six locations do the majority of households achieve food self-sufficiency or food security. Of the scenarios tested, the first two - raising all farmers yields to half and $100 \%$ of the maximum yield achieved locally - are the most feasible. These are moderate increases in productivity: for example, the scenarios would imply raising maize yields from Ya of $200-1100 \mathrm{~kg} \mathrm{ha}^{-1}$ across the sites to $Y_{\mathrm{HF}}$ of $1100-2650 \mathrm{~kg} \mathrm{ha}^{-1}$ (Table 4). In four of the locations, Ethiopia, Tanzania, Ghana and Malawi, land is so constraining that by narrowing yield gaps as far as possible only $42-53 \%$ of households would be food self-sufficient. Essentially, households that are already food secure have larger land areas and will benefit from closing yield gaps, but food insecure households simply have insufficient land to achieve food self-sufficiency.

A surprising outcome is the marginal difference between food self-sufficiency and the food availability indicator where all household income is converted into calories to indicate whether households can be food secure (Fig. 5). Only small increases in the proportion of households above the threshold is seen in each case, even though this analysis also includes the increase in income from closing yield gaps of cash crops. This is because it is largely the better-off, food-secure farmers who are already above the thresholds also have larger areas of cash crops and therefore benefit the most from the yield increases. Ritzema et al. (2017) conducted a similar analysis across seven countries in East Africa and also concluded that raising yields would have little impact on the most food-inadequate households. Of course we make a major assumption in these scenarios, namely that all farming households would be equally able to increase their yields. Yet, poorer households have few resources to invest in new technology to increase yields (Franke et al., 2014). So although closing yield gaps through sustainable intensification would no doubt assist the poorer households to improve their food self-sufficiency, their capacity to invest in technology is limited. The largest benefits are likely to accrue to the better-off households because of their greater capacity to invest and their larger land areas, although they already tend to achieve better yields.

Whilst narrowing yield gaps would clearly increase the proportion of households achieving food self-sufficiency and food security, the effects on raising households out of poverty are much smaller (Fig. 6). Only in Uganda and Mali, where farms are larger and a greater part of the land is devoted to cash crops, is a substantial proportion of the households lifted above the poverty line or the living income threshold when yield gaps are closed. In the other locations closing yield gaps has a surprisingly small impact on the economic status of the majority of households.

\section{Smallholder food security and poverty}

The six locations presented represent but a glimpse of the agroecologies and diversity of farming systems across subSaharan Africa. However, some clear and stark similarities seem to hold across the sites. In the best case $97 \%$ of the households achieve food self-sufficiency, but in the worst case only $10 \%$ of the households (Fig. 5). The incidence of poverty is rife and very few households in most locations achieve a living income - in the best case only one third of the households is able to do so (Fig. 6). Farmers' own production is a major component of food security and income but cash-cropping and / or off-farm income are also very important (cf. Frelat et al., 2016). Detailed studies conducted in each of these locations confirm these general conclusions. For example, in Mali, the better land availability per person and state support for cotton production has allowed a larger proportion of the households to be food secure and maintain a living income (Falconnier et al., 2015). By contrast in Northern Ghana, with similar rainfall and soils to the location in Mali, but with less income from cash crops food security and income are the worst of all the six locations. Paradoxically, the Ethiopian and Tanzanian locations in the East African highlands, which have the best soils and climate for crop production are among the least food secure. The high population density in the Ethiopian highlands has led to shrinking farms and abandonment of diverse home garden systems (Mellisse et al., 2018). In these highlands severe land fragmentation under influence of population pressure results in current farms failing to provide decent livelihoods from a food security and income perspective.

Apart from targeting food self-sufficiency, market-led rather than production-led approaches to food security and rural development, lie at the core of a food systems approach. Indeed 'linking farmers to markets' has been something of a mantra for agricultural development over the past decades. For example, linking smallholders with functioning markets "plays a critical part in long-term 
Fig. 5 Percentage of households achieving a Food SelfSufficiency or b Food Availability above the threshold of $2500 \mathrm{kcal} \mathrm{MAE}^{-1} \mathrm{day}^{-1}$ with current yields (Ya), or under scenarios where all farmers achieve $50 \%$ of the highest farmer $\left(\mathrm{Y}_{\mathrm{HF}}\right), 100 \%$ of the highest farmer yield $\left(\mathrm{Y}_{\mathrm{HF}}\right)$, and when raised to locally attainable yields $\left(\mathrm{Y}_{\mathrm{ATT}}\right)$
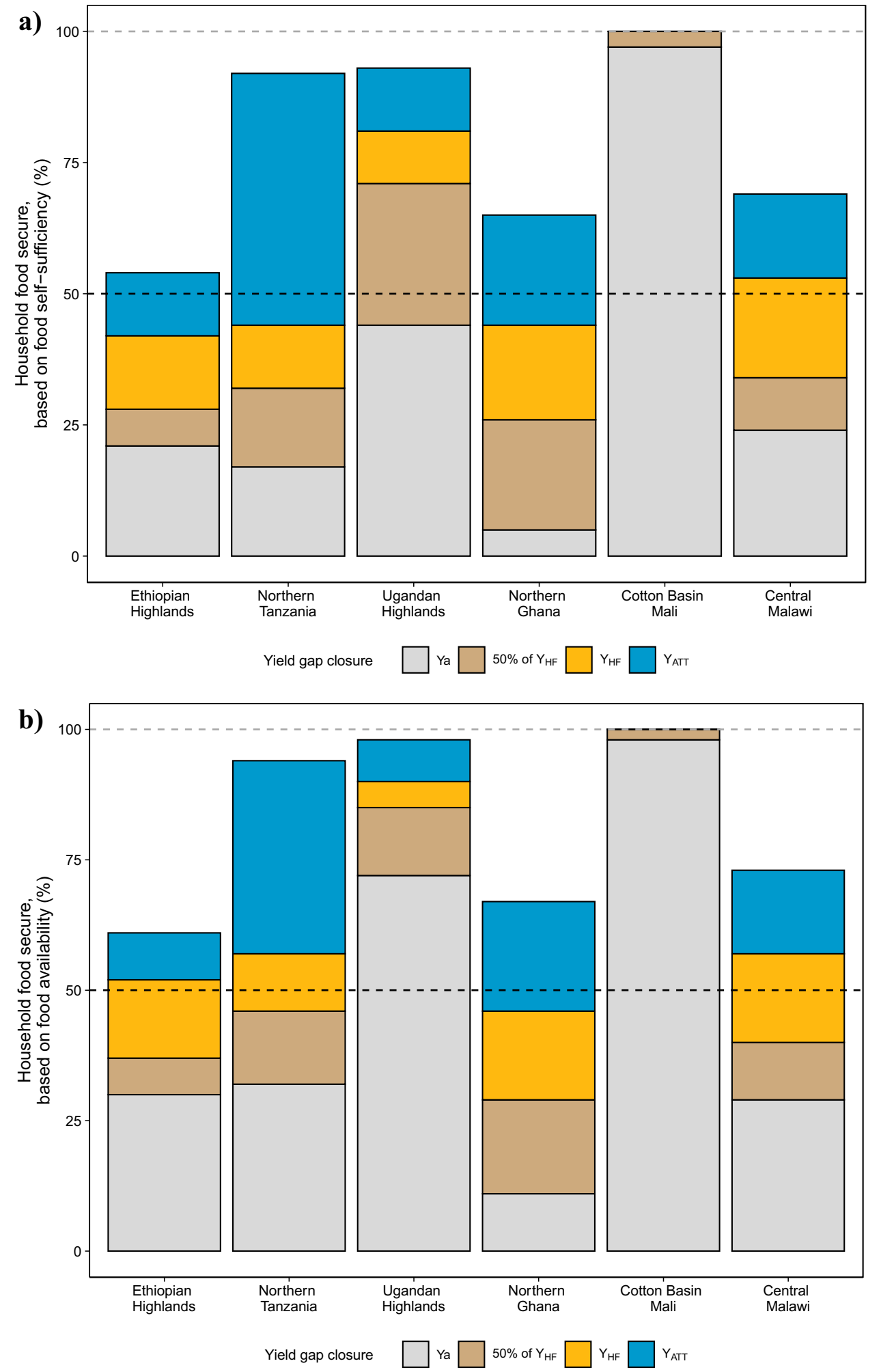

strategies to reduce rural poverty and hunger" (e.g. Seville et al., 2011). Value chain approaches remain central to strategies for development of the rural economy (Christiaensen, 2020; de Janvry \& Sadoulet, 2020), in response to the observation of new-institutional economists that smallholder farmers often operate in 'thin markets', in which volumes traded are low and risks of trading are high. To engage profitably in such markets - with small volumes to trade - requires high margins but in thin markets, the high product prices this requires, only depress 
Table 4 Overview of the most frequently cultivated crops in the RHoMIS study sites and their corresponding actual yield (Ya), highest farmer yield $\left(\mathrm{Y}_{\mathrm{HF}}\right)$, and locally attainable yield $\left(\mathrm{Y}_{\mathrm{ATT}}\right)$

\begin{tabular}{|c|c|c|c|c|c|c|}
\hline Study site & Crops selected & $\begin{array}{l}\text { Household } \\
\text { cultivating } \\
\text { No }\end{array}$ & $\begin{array}{l}\text { Household } \\
\text { Cultivating } \\
\%\end{array}$ & $\begin{array}{l}\text { Actual } \\
\text { yield } \\
(\mathrm{Ya})^{\mathrm{a}} \\
\mathrm{kg} \mathrm{ha}^{-1}\end{array}$ & $\begin{array}{l}\text { Highest } \\
\text { farmer yield } \\
\left(\mathrm{Y}_{\mathrm{HF}}\right)^{\mathrm{b}} \\
\mathrm{kg} \mathrm{ha}^{-1}\end{array}$ & $\begin{array}{l}\text { Attainable } \\
\left.\text { yield ( } \mathrm{Y}_{\text {ATT }}\right) \\
\mathrm{kg} \mathrm{ha}^{-1}\end{array}$ \\
\hline \multirow{5}{*}{$\begin{array}{l}\text { Ethiopian highlands } \\
(n=177)\end{array}$} & Maize & 100 & 56 & 800 & 2700 & 6000 \\
\hline & Haricot bean & 109 & 62 & 650 & 2000 & 2000 \\
\hline & Faba bean & 44 & 25 & 900 & 2000 & 2000 \\
\hline & Vegetables & 34 & 19 & 3400 & 10,000 & 10,000 \\
\hline & Teff & 34 & 19 & 500 & 1900 & 1900 \\
\hline \multirow{5}{*}{$\begin{array}{l}\text { Northern Ghana } \\
(n=319)\end{array}$} & Maize & 213 & 67 & 200 & 1250 & 3500 \\
\hline & Groundnut & 197 & 62 & 150 & 700 & 2000 \\
\hline & Rice & 144 & 45 & 200 & 850 & 3000 \\
\hline & Millet & 114 & 36 & 200 & 750 & 2000 \\
\hline & Cowpea & 60 & 19 & 100 & 350 & 2000 \\
\hline \multirow{5}{*}{$\begin{array}{l}\text { Cotton Basin Mali } \\
(n=64)\end{array}$} & Maize & 62 & 97 & 1150 & 2300 & 5000 \\
\hline & Millet & 62 & 97 & 700 & 1350 & 2000 \\
\hline & Cotton & 61 & 95 & 800 & 1800 & 1800 \\
\hline & Sorghum & 54 & 84 & 400 & 950 & 2000 \\
\hline & Groundnut & 42 & 66 & 500 & 1500 & 3000 \\
\hline \multirow{4}{*}{$\begin{array}{l}\text { Central Malawi }^{\mathrm{c}} \\
(n=131)\end{array}$} & Maize & 124 & 95 & 900 & 2650 & 5000 \\
\hline & Groundnut & 27 & 21 & 950 & 2950 & 3000 \\
\hline & Vegetables & 13 & 10 & 200 & 17,000 & 17,000 \\
\hline & Soybean & 11 & 8 & 100 & 200 & 2500 \\
\hline \multirow{5}{*}{$\begin{array}{l}\text { Northern Tanzania } \\
(n=95)\end{array}$} & Maize & 93 & 98 & 200 & 1100 & 5000 \\
\hline & Common bean & 79 & 83 & 200 & 550 & 1800 \\
\hline & Irish potato & 24 & 25 & 600 & 1300 & 15,000 \\
\hline & Banana & 14 & 15 & 8250 & 18,500 & 60,000 \\
\hline & Tomatoes & 12 & 13 & 6300 & 19,500 & 19,500 \\
\hline \multirow{3}{*}{$\begin{array}{l}\text { Ugandan Highlands }{ }^{\mathrm{c}} \\
(n=88)\end{array}$} & Coffee & 80 & 91 & 150 & 650 & 2000 \\
\hline & Banana & 77 & 88 & 4500 & 18,450 & 60,000 \\
\hline & Cassava & 54 & 61 & 200 & 800 & 37,000 \\
\hline
\end{tabular}

${ }^{a}$ Median yield per crop at each study site

b $90^{\text {th }}$ percentile yield per crop at each study site

${ }^{c}$ Central Malawi: only four crops were reported in the survey; Ugandan Highlands: maize and common beans are frequently grown but not included due to a large proportion of missing yield data demand. The resulting 'Catch-22' is a low-level equilibrium trap and market failure (Dorward et al., 2009). Recognising the huge diversity among smallholder farmers, Vorley (2002) created a typology of three 'Rural Worlds' and linked resource endowment to livelihoods and market participation. Rural World 1 is comprised of farmers who are well-embedded in national and international markets. Rural World 2 is comprised of more locally-focused family farmers who may have the opportunity to take advantage of value chain approaches and actively participate in markets given appropriate opportunities. Households that fall into Rural World 3 have fragile livelihoods with poor access to productive resources. Their opportunities beyond wagelabour and farming for food security are limited (Seville et al., 2011; Vorley, 2002; Vorley et al., 2012). This classification resonates with the livelihood strategies identified by Dorward (2009) as 'stepping up', 'stepping out' - for those with the means to escape farming to other occupations - and the fragile livelihoods that have 'hanging in' as the only option. It also resonates with diverse farm types identified within rural communities in sub-Saharan Africa (Giller et al., 2011). Building on our analysis of smallholder farms, a crucial question concerning value chain approaches is what proportion of the farms in SSA have sufficient means to rely on an agriculture-based future without falling into poverty. That is, what proportion of farmers can 'step up' into Rural World 1 and earn a living income from agriculture? And under what conditions are value-chain approaches likely to play a central role in improving rural livelihoods?

Vorley et al. (2012) assumed that households which control less than 0.11 ha capita $^{-1}$ can be categorized as 
Fig. 6 Percentage of households earning an income above a the absolute poverty line of USD $1.9 /$ per person/day or $\mathbf{b}$ a local living income (USD ppp /AE/ day) with current yields (Ya), or under scenarios where all farmers achieve $50 \%$ of the highest farmer yield $\left(\mathrm{Y}_{\mathrm{HF}}\right), 100 \%$ of the highest farmer yield $\left(\mathrm{Y}_{\mathrm{HF}}\right)$, and when raised to locally-attainable yields $\left(\mathrm{Y}_{\mathrm{ATT}}\right)$
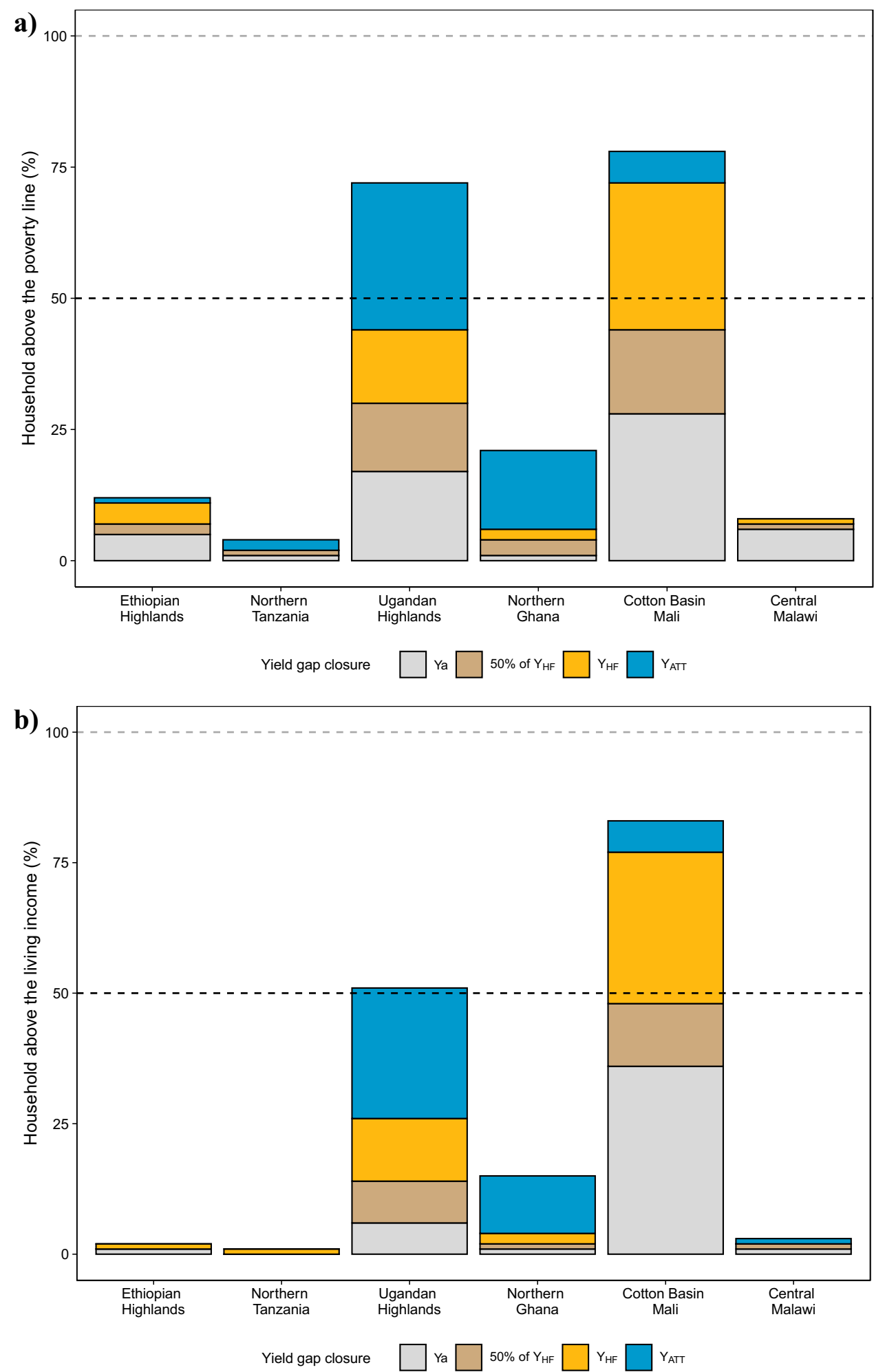

Rural World 3 and estimated that at least $25 \%$ of the households in SSA belong to this category (Fig. S1). However, when Seville et al. (2011) examined farmers' opportunities through a market lens, they estimated that $40-50 \%$ derive most of their income from off-farm labour. Those could also be categorized as Rural World 3. Similarly, Ferris et al. (2014) estimated that 45-55\% are vulnerable farmers with infrequent market access, limited by land and education, some of them are 'ultra-poor'. Jayne et al. (2010) sketched an even gloomier picture of Eastern and Southern Africa where 
$1-4 \%$ of farmers sell $50 \%$ of the staple grains they produce, 20-30\% sell small quantities ranging between 0.1 and $1 \mathrm{t}$ household ${ }^{-1}$ and 50-70\% are net buyers of staple grains.

We quantified the Rural Worlds based on the household survey data across locations using current household incomes. We assumed those who already achieve a living income from farming were part of Rural World 1, those above the poverty line but currently failing to achieve a living income would be able to 'step-up' and therefore belong to Rural World 2, and households with an income below the absolute poverty line belong to Rural World 3 . Again, the results highlight the large differences among the different farming systems. Across locations, the vast majority $(>80 \%)$ of households fall into Rural World 3 (Table 5), far more than the $25 \%$ estimate from Vorley et al. (2012) based on land sizes, the 40-55\% estimates from Seville et al. (2011) and Ferris et al. (2014) based on market participation and the 50-70\% estimate from Jayne et al. (2010) (Fig. S1). Only in Mali where cotton is an important cash crop were $16 \%$ of households classified as Rural World 1 and able to make a living income from farming. Further, there is a large gap between Rural Worlds 1 and 3, with few households falling into Rural World 2 across all sites.

Harris and Orr (2013) reviewing the impact of agricultural innovations on the income of smallholders conclude that dryland farming alone is unlikely to offer a pathway from poverty for most smallholders, even under optimistic scenarios regarding the economic impact of improved technologies at scale. Similarly, several authors suggest that a doubling or tripling of crop income will have little impact on households' absolute poverty rates (Franke et al., 2014; Harris \& Orr, 2013; Jayne et al., 2010; Mabiso et al., 2014). Access to input and output markets is undoubtedly important for smallholders. Indeed, smallholder farmers are often involved in multiple value chains, selling both food and cash crops which represent important income streams (Leonardo et al., 2015b). But the greatest benefits from value chain approaches will clearly be accrued by those households with sufficient resources of land, labour and capital to invest and are thus an option for a limited proportion of households.

\section{Potential impacts of population growth on agriculture}

Population growth across sub-Saharan Africa is rapid and is projected to continue for several decades even under the most optimistic scenarios (Vollset et al., 2020). What does this mean in terms of pressure on land for agriculture? As our analysis above shows, farm sizes are already small. As a broad approximation, if we divide the existing area of cropland per country by its current population, the majority of countries already have 4-6 persons per ha of cropland (Fig. 7). Extrapolation of current trends suggest that Africa's population will have doubled by 2050 , indicating a population pressure of 8-12 persons per ha of cropland, when there is no further expansion of cropland. This would mean a further contraction of farm sizes in the countries which are already densely-populated, and further expansion of the area of cropland in land-abundant areas appears to be inevitable.

\section{Rethinking the role of smallholder agriculture in rural livelihoods}

The six examples of farming systems analysed here demonstrate (a small fraction of) the enormous diversity of farming systems across sub-Saharan Africa. Perhaps the most stark result is the large proportion of households that fail to achieve food security - as indicated by the food availability indicator - even when all income streams are converted into calories. To raise the majority of households above the threshold for food availability would require a massive increase in productivity to narrow yield gaps; yet it seems that the incentives to invest in productivity improvement are very limited, especially for the households in Rural World
Table 5 The percentage of households in each of the RHoMIS locations reported in Table 3 who fall into each of the 'Rural Worlds' based on all income earned on farm (i.e. excluding all off-farm income) compared with the local living income threshold and the absolute poverty line of USD $1.9 \mathrm{ppp} \mathrm{AE}^{-1} \mathrm{day}^{-1}$

\begin{tabular}{|c|c|c|c|c|c|c|}
\hline & $\begin{array}{l}\text { Ethiopian High- } \\
\text { lands }\end{array}$ & Northern Tanzania & $\begin{array}{l}\text { Ugandan High- } \\
\text { lands }\end{array}$ & Northern Ghana & Cotton Basin Mali & $\begin{array}{l}\text { Central } \\
\text { Malawi }\end{array}$ \\
\hline $\begin{array}{l}\text { Rural World } 1 \\
\text { > Living income }\end{array}$ & 1 & 0 & 2 & 0.5 & 16 & 0 \\
\hline $\begin{array}{l}\text { Rural World } 2 \\
\text { USD } 1.9 \text { ppp } \mathrm{AE}^{-1} \text { day }^{-1}- \\
\text { Living income }\end{array}$ & 2 & 1 & 8 & 0.5 & 0 & 2 \\
\hline $\begin{array}{l}\text { Rural World } 3 \\
<\text { USD } 1.9 \text { ppp AE } \text { day }^{-1}\end{array}$ & 97 & 99 & 90 & 99 & 84 & 98 \\
\hline
\end{tabular}


Fig. 7 Population density per ha of cropland in 2015 a and in 2050 for the projected number of inhabitants with maximum expansion $\mathbf{b}$ or no expansion $\mathbf{c}$ of suitable agricultural areas for 39 African countries. Current cropland area was derived from FAOSTAT (http://www.fao.org/ faostat/en/\#home), the projected number of inhabitants per country in 2050 were derived from the United Nations World Population Prospects, 2017 revision (https://population.un. org/wpp/Download/

Standard/Population/). The suitable agricultural areas were derived from Chamberlin et al. (2014).
2015 - Actual situation

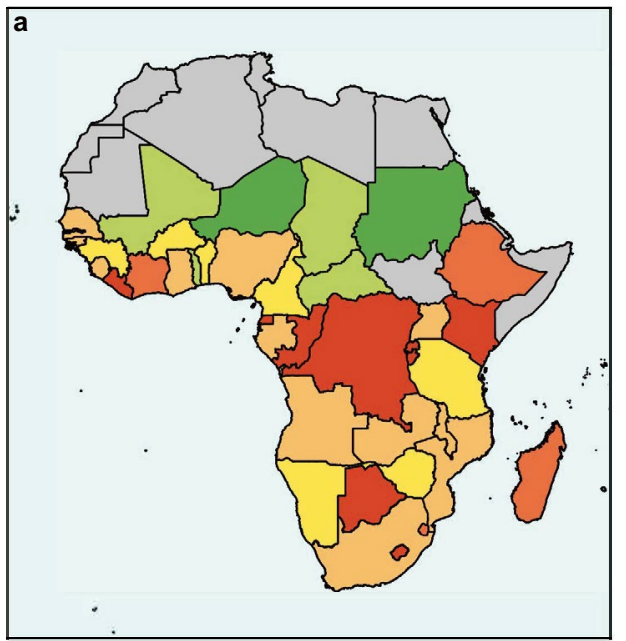

2050 - Cropland expanded

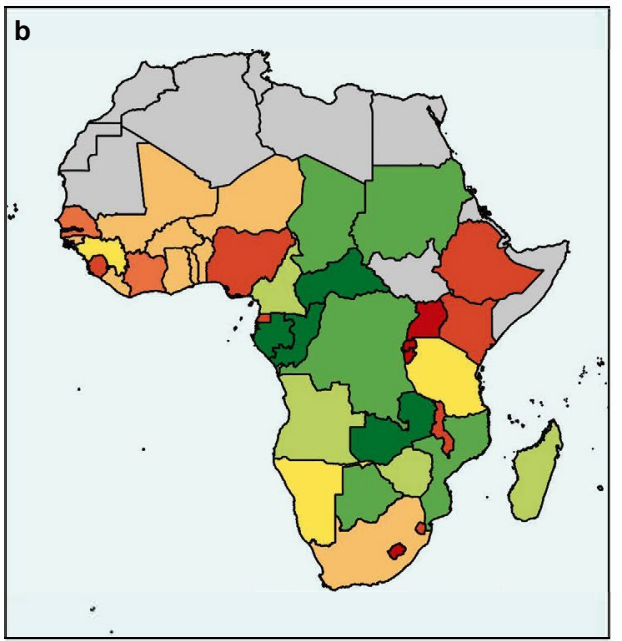

d

LEGEND

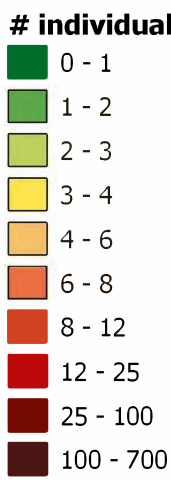

2050 - Cropland not expanded

c

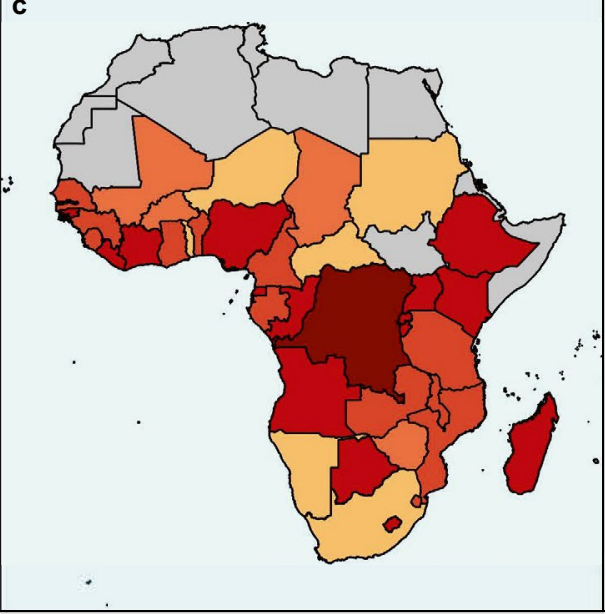

3. There is a huge diversity in food security and income levels among households within each locality, confirming earlier results that examined patterns of food availability across Uganda (Waha et al., 2018; Wichern et al., 2017). Yet, poverty and food insecurity are widespread in most locations. Further, our analysis highlights that a (very) small proportion of rural households can earn a living income from farming alone.

It is clear from the analysis above that rural livelihoods are multi-faceted, with virtually all households relying on a wide-range of activities and income streams. Agricultural production of crops and livestock is important for food and nutrition security and for income, but needs to be seen alongside other off-farm activities. The reliance of rural households on diverse activities is well recognised in the literature (e.g. Ellis, 1998) but often overlooked in discussions on potential development interventions, particularly those based on agriculture. Rural households are often referred to as 'subsistence' farmers - implying that their focus is purely on farming for survival. Our analysis and a growing body of literature from other scholars questions this perspective drawing attention to the constraints of small farm sizes (e.g. Franke et al., 2014; Harris \& Orr, 2013; Muyanga \& Jayne, 2014) and the aspirations of rural people to focus on employment outside the farm (Dilley et al., 2021; Mausch et al., 2018). So what role does the farm play in the livelihood of rural households?

Where cash cropping is lucrative, agricultural production can provide a living income for households with sufficient land and labour resources, as we see with the example of cotton production in Mali. In terms of general trends, Frelat et al. (2016) found that across countries and locations the households that produced the most food also produced more cash crops and livestock, as well as relying more on off-farm income. This raises the chicken and egg question, as to whether agriculture is the driving factor in raising incomes, or whether non-farm income is needed to raise the agricultural productivity. Smallholder farming systems are dominated by staple crop production for a number of reasons. First, cash is scarce and farms are 
small, and often incapable of generating enough food for the family. Second, there is always a market for staple crops even if they are not particularly profitable. Which types of products make 'commercial sense' for smallholders depends on the agroecological conditions - perennial commodities such as coffee and tea are ideal for the highlands. Cocoa and oil palm provide opportunities in lowland humid regions. Vegetables generate a good source of income for smallholders with access to land in valleys or where irrigation is possible. Livestock offer other opportunities. Dairy farming provides a regular income from sale of milk but requires good infrastructure to be scaled up to meet urban demands. The growing demand for poultry and eggs in urban centres also offers market opportunities for small-scale production.

The fact that off-farm opportunities are often prioritised above crop and livestock production highlights the poor remuneration from farming, yet this does not mean that agricultural research and development cannot assist in reducing hunger and drudgery. Empirical studies in SSA showed that for the poorest people, agricultural growth reduced poverty 11 times more than non-agricultural growth (Christiaensen et al., 2011). As long as there are no better options outside farming, research and development can help small-scale and poor farmers to achieve better food security and relatively small, but nevertheless important, increases in income. Indeed even for the youth in Kenya, farming remains one of the livelihood options they would like to pursue, though not in isolation (LaRue et al., 2020).

Opportunities to earn income off-farm also present opportunity costs relating to production on-farm. Employment to earn food or income for work in rural areas is highly seasonal. The busiest times of the year in rural areas are generally at the start or early in the cropping season when soils need to be tilled, seed sown and weeds removed. The greatest food shortages - the hunger season - often coincide with peak labour demand for weeding and when many members of poorer households work for food (e.g. Bouwman et al., 2020; Leonardo et al., 2015a). When the income earned off-farm is too small to compensate absence by hiring in labour, this causes delay in attention to own crops resulting in yield penalties due to late planting and weeding (Kamanga et al., 2010).

Seasonality is of critical importance for food and nutrition security in other ways. Long dry seasons are associated with a strongly-reduced diversity of foodstuffs available on farm or in the market. Storage of staple cereal crops may allow to sustain the calorie requirements of households during the long dry season, highlighting the need for secure storage to prevent post-harvest loss (Milgroom \& Giller, 2013). But all households face a critical shortage of fresh foods and in particular of micronutrients and vitamins in the dry season (see the poor dietary diversity scores for the bad season in Table 3). It is hard to produce a year-round, balanced diet unless water is available to irrigate plots and grow vegetables in the dry season. Even considering all of the foods available in the local markets it was impossible to create a complete diet all year round that met all standards for human nutrition in northern Ghana (de Jager, 2019). So, although it may be desirable to re-design farming systems around local production of a diverse array of foods to provide a nutritious food basket, this is challenged by the seasonal nature of crop production.

Farming is also a risky business, with frequent crop failure in drier regions and the looming impacts of climate change. Changing weather patterns and the increased variability and unpredictability of the weather are expected to lead to changes in the suitability of crop and livestock systems, as shown by Wichern et al. (2019) for Uganda. With large sensitivity (e.g. Rurinda et al., 2015; Traore et al., 2017) and small adaptive capacity, smallholders are particularly vulnerable to climate change (Descheemaeker et al., 2016). Perhaps not surprisingly, smallholders in southern Mali perceived climate variability as the greatest risk they faced, after their own and their animals' health (Huet et al., 2020). In such variable climates, smallholder systems are usually managed to minimize downside risk. Although increasing inputs would increase average yields, it also leads to larger year-to-year variability, which acts as a barrier against investments needed to narrow yield gaps (Descheemaeker et al., 2020).

Some authors have suggested that there may be a threshold under which farms become too small to be economically viable (e.g.Harris \& Orr, 2013; Tittonell \& Giller, 2013). Stephens et al. (2012) suggested a threshold farm size of 0.7 ha in Western Kenya. Hazell et al. (2007), on the other hand, defined farms as being 'large enough' to be optimistic about the prospects of smallholder development when they have 'as little as 1 ha of irrigated land, and as much as 3 ha for rainfed cropland'. However, a threshold for an economically viable land size greatly depends on the biophysical potential of the land and climatic and socio-economic conditions, including opportunities for irrigated farming, amount and distribution of rainfall and access to markets. The threshold therefore is likely to vary considerably between farms within regions and even more between regions. Moreover, land alone is no guarantee for successful commercialisation of agricultural production. Farmers also need the incentives and capacity to adopt new technologies and invest in their land. Several studies have shown that resource endowments other than land, such as access to capital or knowledge, are critical to invest in and adopt new technologies (e.g. Marenya \& Barrett, 2007). In densely-populated areas it seems inevitable that some degree of aggregation of farms is needed to allow adoption of the basic technologies needed to benefit from sustainable intensification (Aune et al., 2019; Jayne et al., 2019). 
Against the backdrop of increasing population pressure and fragmentation of farms, there is evidence of a countervailing trend. A new cadre of medium-scale 'investor farmers' with land areas of 5-100 ha is expanding rapidly (Jayne et al., 2016). These investor farmers are urban professionals or rural elite households (Sitko \& Jayne, 2014) who already control $20-50 \%$ of the total farmland in Kenya, Ghana, Tanzania and Zambia. Jayne et al. (2016) highlight that the share of arable land under the control of urban based households is rising, leading to rapid increases in land prices within $100 \mathrm{~km}$ of urban centres. Often only a small proportion of the land acquired is initially used (Jayne et al., 2014). Such farms can help to stimulate local input and output markets, but the implications for local farmers are unclear. Given the continuing population growth in rural areas it seems inevitable that the consolidation of land in the hands of investor farmers will contribute to further marginalisation of poorer households (Jayne et al., 2014). If such farms are successful in improving their production they could be important for addressing national food security.

\section{Conclusions}

To avoid further marginalization of rural households and expansion of the population into land not yet used for agriculture, a fundamental transformation of the farming systems in sub-Saharan Africa appears inevitable. But as we show above, the options for agricultural intensification are limited by small farm sizes and the lack of economic incentives. Notwithstanding potential issues with the accuracy of household survey data, our analyses suggest that farm sizes are generally small ( $<1 \mathrm{ha}$ ), and far smaller than often assumed in analyses of food security in sub-Saharan Africa-although farm areas tend to be larger in drier agroecological zones. Even if yield gaps are closed, food insecurity and poverty will remain and only a small proportion of the rural population could derive a living income from farming alone. Contrary to what we might expect, some of the farming systems in the East African highlands, which have the best agroecological potential in terms of climate and soils, are among the least food secure and furthest from being able to earn a living income from farming. This is largely due to land fragmentation arising from population growth.

To return to the food security conundrum, the large yield gaps and the increasing demand for agricultural produce - to feed the rapidly growing population - pose a major opportunity to develop the agricultural sector. Agricultural development has proven to be key to reducing poverty and hunger (Koning, 2017; Timmer, 2009), yet we question the common assumption that economic development in Africa can be driven by agriculture given current trends. We cannot assume that rural households will invest in technologies to increase their yields unless these are profitable and make a difference in terms of income and food security. Given the lack of livelihood security provided by agriculture, concurrent development of offfarm employment is required. Social safety nets are needed to tackle poverty, such as provision of a universal basic income (Banerjee \& Duflo, 2019). An important, first step in reframing the debate around agricultural development in sub-Saharan Africa would be to cease to refer to 'subsistence' farming as farming on such small farms neither is sufficient to survive, nor is it a full-time occupation from which one can make a living. Farming is no doubt important for both the food supply and income of rural households, but as one enterprise among a diverse livelihood portfolio competing with options to earn a living outside agriculture.

Supplementary Information The online version contains supplementary material available at https://doi.org/10.1007/s12571-021-01209-0.

Acknowledgements We are grateful to the International Fund for Agricultural Development (IFAD) for funding much of the data analysis as part of the Towards Inclusive, Sustainable, Nutritious and Efficient Food Systems project. KEG thanks the NWO-WOTRO Strategic Partnership NL-CGIAR for funding. JA acknowledges funding from the CRP on Maize through the CIMMYT grant 'Rural livelihood-oriented research methodologies for social impact analyses of Sustainable Intensification interventions' project. JH acknowledges funding from USAID Feed the Future-AfricaRISING Ethiopia and JH and MvW the CGIAR Research Program on Livestock. We thank Rhett Harrison for permission to use RHoMIS data from Malawi collected by the NORAD-funded 'Developing smallholder strategies for fall armyworm management in southern Africa' project implemented jointly by ICRAF and Department of Agricultural Research, Malawi, Jordan Chamberlin for sharing data on available cropland at country level in sub-Saharan Africa and Bastiaen Boekelo for preparing Fig. 7.

\section{Declarations}

Conflict of Interest The authors declare that they have no conflict of interest.

Open Access This article is licensed under a Creative Commons Attribution 4.0 International License, which permits use, sharing, adaptation, distribution and reproduction in any medium or format, as long as you give appropriate credit to the original author(s) and the source, provide a link to the Creative Commons licence, and indicate if changes were made. The images or other third party material in this article are included in the article's Creative Commons licence, unless indicated otherwise in a credit line to the material. If material is not included in the article's Creative Commons licence and your intended use is not permitted by statutory regulation or exceeds the permitted use, you will need to obtain permission directly from the copyright holder. To view a copy of this licence, visit http://creativecommons.org/licenses/by/4.0/. 


\section{References}

Aune, J. B., Coulibaly, A., \& Woumou, K. (2019). Intensification of dryland farming in Mali through mechanisation of sowing, fertiliser application and weeding. Archives of Agronomy and Soil Science, 65(3), 400-410. https://doi.org/10.1080/03650340.2018. 1505042

Banerjee, A. V., \& Duflo, E. (2019). Good Economics for Hard Times: Better Answers to Our Biggest Problems: Allen Lane.

Bouwman, T. I., Andersson, J. A., \& Giller, K. E. (2020). Herbicide induced hunger? Conservation Agriculture, ganyu labour and rural poverty in Central Malawi. Journal of Development Studies, 57, 244-263 https://doi.org/10.1080/00220388.00222020.01786062

Buresh, R. J., Sanchez, P. A., \& Calhoun, F. (Eds.). (1997). Replenishing Soil Fertility in Africa (SSSA Special Publication Number 51). Madison, Wisconsin: ASSA, CSSA, SSSA.

Carletto, C., Savastano, S., \& Zezza, A. (2013). Fact or artifact: The impact of measurement errors on the farm size-productivity relationship. Journal of Development Economics, 103, 254-261. https://doi.org/10.1016/j.jdeveco.2013.03.004

Center for International Earth Science Information Network - CIESIN. (2018). Gridded Population of the World, Version 4 (GPWv4): Population Density, Revision 11. Colombia University.

Chamberlin, J., Jayne, T. S., \& Headey, D. (2014). Scarcity amidst abundance? Reassessing the potential for cropland expansion in Africa. Food Policy, 48(C), 51-65. https://doi.org/10.1016/j.foodpol.2014. 05.002

Chanfreau, J., \& Burchardt, T. (2008). Equivalence scales: rationales, uses and assumptions. https://www.gov.scot/Resource/Doc/933/ 0079961.pdf

Christiaensen, L. (2020). Agriculture, Jobs, and Value Chains in Africa. Job Notes Issue No 9 https://openknowledge.worldbank. org/handle/10986/33693. Washington DC.

Christiaensen, L., Demery, L., \& Kuhl, J. (2011). The (evolving) role of agriculture in poverty reduction-An empirical perspective. Journal of Development Economics, 96(2), 239-254. https://doi. org/10.1016/j.jdeveco.2010.10.006

Crowley, E. L., \& Carter, S. E. (2000). Agrarian change and the changing relationships between toil and soil in Maragoli, western Kenya (1900-1994). Human Ecology, 28, 383-414.

de Jager, I. (2019). Harvesting Nutrition: Grain Legumes and Nutritious Diets in sub-Saharan Africa. PhD thesis, Wageningen University, Wageningen.

de Janvry, A., \& Sadoulet, E. (2020). Using agriculture for development: Supply- and demand-side approaches. World Development, 133, 105003. https://doi.org/10.1016/j.worlddev.2020. 105003

Descheemaeker, K., Oosting, S. J., Tui, S.H.-K., Masikati, P., Falconnier, G. N., \& Giller, K. E. (2016). Climate change adaptation and mitigation in smallholder crop-livestock systems in sub-Saharan Africa: A call for integrated impact assessments. Regional Environmental Change, 16, 2331-2343. https://doi.org/10.1007/s10113-016-0957-8

Descheemaeker, K., Reidsma, P., \& Giller, K. E. (2020). Climate-smart crop production: Understanding complexity for achieving triplewins. In D. Deryng (Ed.), Climate change and agriculture (pp. 275-318). Burleigh Dodds Science Publishing.

Dilley, L., Mausch, K., Crossland, M., \& Harris, D. (2021). What's the story on agriculture? Using narratives to understand farming households' aspirations in Meru, Kenya. The European Journal of Development Research, 1-24. https://doi.org/10.1057/ s41287-021-00361-9

Dorward, A. (2009). Integrating contested aspirations, processes and policy: Development as Hanging In, Stepping Up and Stepping Out. Development Policy Review, 27, 131-146.
Dorward, A., Kydd, J., Poulton, C., \& Bezemer, D. (2009). Coordination risk and cost impacts on economic development in poor rural areas. Journal of Development Studies, 45, 1093-1112.

Ellis, F. (1998). Household strategies and rural livelihood diversification. Journal of Development Studies, 35(1), 1-38. https://doi.org/ 10.1080/00220389808422553

Falconnier, G. N., Descheemaeker, K., Van Mourik, T. A., Sanogo, O. M., \& Giller, K. E. (2015). Understanding farm trajectories and development pathways: Two decades of change in southern Mali. Agricultural Systems, 139(C), 210-222. https://doi.org/10.1016/j. agsy.2015.07.005

FAO. (2018). Rural Livelihoods Information System (RuLIS). Statistics Division, September. Available from http://www.fao.org/ in-action/rural-livelihoods-dataset-rulis/bulk-download/derivedmicro-variables/en/. Rome: FAO.

FAO. (2020). FAOSTAT Crop Production [Online]. Available: http:// www.fao.org/faostat/en/\#home

FAO, IFAD, UNICEF, WFP, \& WHO. (2020). The State of Food Security and Nutrition in the World. Transforming Food Systems to Deliver Affordable Healthy Diets for All. Rome: FAO.

Ferris, S., Robbins, P., Best, R., Seville, D., Buxton, A., Shriver, J., et al. (2014). Linking Smallholder Farmers to Markets and the Implications for Extension and Advisory Services. MEAS Discussion Paper 4. Baltimore: CRS/ USAID.

Franke, A. C., van den Brand, G. J., \& Giller, K. E. (2014). Which farmers benefit most from sustainable intensification? An $e x$ ante impact assessment of expanding grain legume production in Malawi. European Journal of Agronomy, 58, 28-38.

Frelat, R., Lopez-Ridaura, S., Giller, K. E., Herrero, M., Douxchamps, S., Djurfeldt, A. A., et al. (2016). Drivers of household food availability in sub-Saharan Africa based on big data from small farms. Proceedings of the National Academy of Sciences, USA, 113, 458-463. https://doi.org/10.1073/pnas.1518384112

Funk, C., Peterson, P., Landsfeld, M., Pedreros, D., Verdin, J., Shukla, S., et al. (2015). The climate hazards infrared precipitation with stations-a new environmental record for monitoring extremes. Scientific Data, 2, 1-21. https://doi.org/10.1038/sdata.2015.66

Gerard, B. (2020). Sustainable intensification of African agriculture: A necessity, but not yet a reality. Frontier Agricultural Science Engineering, 7(4), 383-389. https://doi.org/10.15302/j-fase-2020361.

Giller, K. E. (2020). The food security conundrum of sub-Saharan Africa. Global Food Security, 26, 100431. https://doi.org/10. 1016/j.gfs.2020.100431

Giller, K. E., Delaune, T., Silva, J. V., Descheemaeker, K., van de Ven, G., Schut, A. G. T., et al. (2021). The future of farming: Who will produce our food? Food Security, https://doi.org/10.1007/ s12571-021-01184-6

Giller, K. E., Tittonell, P., Rufino, M. C., van Wijk, M. T., Zingore, S., Mapfumo, P., et al. (2011). Communicating complexity: Integrated assessment of trade-offs concerning soil fertility management within African farming systems to support innovation and development. Agricultural Systems, 104, 191-203. https://doi.org/10.1016/j.agsy.2010.07.002

Godfrey, S., \& Tunhuma, F. A. (2020). The Climate Crisis: Climate Change Impacts, Trends and Vulnerabilities of Children in Sub Sahara Africa,. Nairobi: United Nations Children's Fund Eastern and Southern Africa Regional Office.

Hammond, J., Fraval, S., van Etten, J., Suchini, J. G., Mercado, L., Pagella, T., et al. (2017). The Rural Household Multi-Indicator Survey (RHoMIS) for rapid characterisation of households to inform climate smart agriculture interventions: Description and applications in East Africa and Central America. Agricultural Systems, 151(C), 225-233. https://doi.org/10.1016/j.agsy.2016. 05.003 
Harris, D. (2019). Intensification benefit index: How much can rural households benefit from agricultural intensification? Experimental Agriculture, 55(2), 273-287.

Harris, D., \& Orr, A. (2013). Is rainfed agriculture really a pathway from poverty? Agricultural Systems, 123, 84-96.

Hazell, P., Poulton, C., Wiggins, S., \& Dorward, A. (2007). The future of small farms for poverty reduction and growth. 2020 Discussion Paper 42. Washington, DC: IFPRI.

Hengsdijk, H., Franke, A. C., van Wijk, M. T., \& Giller, K. E. (2014). How small is beautiful? Food self-sufficiency and land gap analysis of smallholders in humid and semi-arid sub Saharan Africa. Plant Research International, Wageningen UR, 68. https://edepot.wur.nl/331203

Herrmann, S. M., \& Mohr, K. I. (2011). A continental-scale classification of rainfall seasonality regimes in Africa based on gridded precipitation and land surface temperature products. Journal of Applied Meteorology and Climatology, 50, 2504-2513. https:// doi.org/10.1175/JAMC-D-11-024.1

Holden, S., Shiferaw, B., \& Pender, J. (2001). Market Imperfections and Land Productivity in the Ethiopian Highlands. Journal of Agricultural Economics, 52(3), 53-70. https://doi.org/10.1111/j. 1477-9552.2001.tb00938.x

Huet, E. K., Adam, M., Giller, K. E., \& Descheemaeker, K. (2020). Diversity in perception and management of farming risks in southern Mali. Agricultural Systems, 184, 102905. https://doi. org/10.1016/j.agsy.2020.102905

Huijzendveld, F. (1997). Die Ostafrikanische Schweiz: Plantages, Planters en Plattelandsontwikkeling in West-Usumbara, Oost Afrika, ca. 1870-1930. Hilversum: Verloren.

IFPRI. (2015). Agroecological Zones for Africa South of the Sahara. Harvard Dataverse. Available from https://doi.org/10.7910/DVN/ M7XIUB Washington, DC: IFPRI.

Jayne, T. S., Chamberlin, J., Traub, L., Sitko, N., Muyanga, M., Yeboah, F. K., et al. (2016). Africa's changing farm size distribution patterns: The rise of medium-scale farms. Agricultural Economics, 47(S1), 197-214. https://doi.org/10.1111/agec.12308

Jayne, T. S., Chapoto, A., Sitko, N., Nkonde, C., Muyanga, M., \& Chamberlin, J. (2014). Is the scramble for land in Africa foreclosing a smallholder agricultural expansion strategy? Journal of International Affairs, 67, 35-52.

Jayne, T. S., Mather, D., \& Mghenyi, E. (2010). Principal challenges confronting smallholder agriculture in sub-Saharan Africa. World Development, 38(10), 1384-1398. https://doi.org/10.1016/j.world dev.2010.06.002

Jayne, T. S., Snapp, S., Place, F., \& Sitko, N. (2019). Sustainable agricultural intensification in an era of rural transformation in Africa. Global Food Security, 20, 105-113. https://doi.org/10.1016/j.gfs. 2019.01.008

Kamanga, B. C. G., Whitbread, A., Wall, P., Waddington, S. R., Almekinders, C., \& Giller, K. E. (2010). Farmer evaluation of phosphorus fertilizer application to annual legumes in Chisepo, Central Malawi. African Journal of Agricultural Research, 5, 668-680.

Kilic, T., Winters, P., \& Carletto, C. (2015). Gender and agriculture in sub-Saharan Africa: Introduction to the special issue. Agricultural Economics, 46(3), 281-284. https://doi.org/10.1111/agec. 12165

Koning, N. (2017). Food Security, Agricultural Policies and Economic Growth. Long-term Dynamics in the Past, Present and Future. Abingdon, Oxon: Routledge.

LaRue, K., Daum, T., Mausch, K., \& Harris, D. (2020). Who Wants to Farm? Answers Depend on How You Ask: A Case Study on Youth Aspirations in Kenya. The European Journal of Development Research, 1-25. https://doi.org/10.1057/s41287-020-00352-2

Leonardo, W. J., van de Ven, G., Udo, H., Kanellopoulos, A., \& Giller, K. E. (2015a). Labour not land constrains agricultural production and food self-sufficiency in maize-based smallholder farming systems in Mozambique. Food Security, 7, 857-874. https://doi. org/10.1007/s12571-015-0480-7

Leonardo, W. J., Bijman, J., \& Slingerland, M. A. (2015b). The Windmill Approach: Combining transaction cost economics and farming systems theory to analyse farmer participation in value chains. Outlook on Agriculture, 44(3), 207-214. https://doi.org/10.5367/ oa. 2015.0212

Lloyd, C. T., Sorichetta, A., \& Tatem, A. J. (2017). High resolution global gridded data for use in population studies. Scientific Data, 4(1), 170001. https://doi.org/10.1038/sdata.2017.1

Lowder, S. K., Skoet, J., \& Raney, T. (2016). The number, size, and distribution of farms, smallholder farms, and family farms worldwide. World Development, 87, 16-29. https://doi.org/10.1016/j. worlddev.2015.10.041

Mabiso, A., Cunguara, B., \& Benfica, R. (2014). Food (In)security and its drivers: Insights from trends and opportunities in rural Mozambique. Food Security, 6(5), 649-670. https://doi.org/10. 1007/s12571-014-0381-1

Marenya, P., \& Barrett, C. (2007). Household-level determinants of adoption of improved natural resources management practices among smallholder farmers in western Kenya. Food Policy, 32, 515-536.

Mausch, K., Harris, D., Heather, E., Jones, E., Yim, J., \& Hauser, M. (2018). Households' aspirations for rural development through agriculture. Outlook on Agriculture, 47(2), 108-115. https://doi. org/10.1177/0030727018766940

McCracken, J. (2012). A History of Malawi, 1859-1966. Woodbridge, Suffolk: James Currey.

Mellisse, B. T., Descheemaeker, K., Giller, K. E., Abebe, T., \& van de Ven, G. W. J. (2018). Are traditional home gardens in southern Ethiopia heading for extinction? Implications for productivity, plant species richness and food security. Agriculture, Ecosystems and Environment, 252, 1-13. https://doi.org/10.1016/j.agee.2017. 09.026

Milgroom, J., \& Giller, K. E. (2013). Courting the rain: Rethinking seasonality and adaptation to recurrent drought in semi-arid southern Africa. Agricultural Systems, 118(C), 91-104. https://doi.org/10. 1016/j.agsy.2013.03.002

Muyanga, M., \& Jayne, T. S. (2014). Effects of rising rural population density on smallholder agriculture in Kenya. Food Policy, 48(C), 98-113. https://doi.org/10.1016/j.foodpol.2014.03.001

Ritzema, R. S., Frelat, R., Douxchamps, S., Silvestri, S., Rufino, M. C., Herrero, M., et al. (2017). Is production intensification likely to make farm households food-adequate? A simple food availability analysis across smallholder farming systems from East and West Africa. Food Security, 9, 115-131. https://doi.org/10.1007/ s12571-016-0638-y

Rurinda, J., van Wijk, M. T., Mapfumo, P., Descheemaeker, K., Supit, I., \& Giller, K. E. (2015). Climate change and maize yield in southern Africa: What can farm management do? Global Change Biology, 21(12), 4588-4601. https://doi.org/10.1111/gcb.13061

Samberg, L. H., Gerber, J. S., Ramankutty, N., Herrero, M., \& West, P. C. (2016). Subnational distribution of average farm size and smallholder contributions to global food production. Environmental Research Letters, 11(12), 1-11. https://doi.org/10.1088/ $1748-9326 / 11 / 12 / 124010$

Sanchez, P. A. (2002). Soil fertility and hunger in Africa. Science, 295(5562), 2019-2020.

Seville, D., Buxton, A., \& Vorley, B. (2011). Under what conditions are value chains effective tools for pro-poor development? (p. 49). International Institute for Environment and Development/ Sustainable Food Lab.

Silva, J. V., Reidsma, P., Laborte, A. G., \& van Ittersum, M. K. (2017). Explaining rice yields and yield gaps in Central Luzon, Philippines: An application of stochastic frontier analysis and crop 
modelling. European Journal of Agronomy, 82(Part B), 223241. https://doi.org/10.1016/j.eja.2016.06.017

Sitko, N. J., \& Jayne, T. S. (2014). Structural transformation or elite land capture? The growth of "emergent" farmers in Zambia. Food Policy, 48(C), 194-202. https://doi.org/10.1016/j.foodpol.2014.05.006

Stephens, E. C., Nicholson, C. F., Brown, D. R., Parsons, D., Barrett, C. B., Lehmann, J., et al. (2012). Modeling the impact of natural resource-based poverty traps on food security in Kenya: The Crops, Livestock and Soils in Smallholder Economic Systems (CLASSES) model. Food Security, 4(3), 423-439. https://doi.org/ 10.1007/s12571-012-0176-1

Timmer, C. P. (2009). A World Without Agriculture: The Structural Transformation in Historical Perspective. The AEI Press.

Tittonell, P., \& Giller, K. E. (2013). When yield gaps are poverty traps: The paradigm of ecological intensification in African smallholder agriculture. Field Crops Research, 143, 76-90. https://doi.org/10. 1016/j.fcr.2012.10.007

Traore, B., Descheemaeker, K., van Wijk, M. T., Corbeels, M., Supit, I., \& Giller, K. E. (2017). Modelling cereal crops to assess future climate risk for family food self-sufficiency in southern Mali. Field Crops Research, 201, 133-145. https://doi.org/10.1016/j. fcr.2016.11.002

United Nations. (2015). Resolution adopted by the General Assembly on 25 September 2015. 70/1 Transforming our world: the 2030 Agenda for Sustainable Development. Washington DC: United Nations General Assemby.

United Nations. (2017). World Population Prospects: The 2017 Revision. New York: Department of Economic and Social Affairs, Population Division, United Nations. https://population.un.org/ wpp/Download/Standard/Population/).

United Nations (2019). World Population Prospects: The 2019 Revision. New York. Online Edition. Rev. 1. Available from https://popul ation.un.org/wpp/Download/Standard/Population/: Department of Economic and Social Affairs, Population Division, United Nations.

van de Ven, G. W. J., de Valença, A., Marinus, W., de Jager, I., Descheemaeker, K., Hekman, W., et al. (2020a). Living income benchmarking of rural households in less-developed countries. Food Security, 145, 309-323. https://doi.org/10.1007/ s12571-12020-01099-12578

van de Ven, G. W. J., de Valença, A., Marinus, W., de Jager, I., Descheemaeker, K. K. E., Hekman, W., et al. (2020b). Living income benchmarking of rural households in low-income countries. Food Security, 145(4), 309-323. https://doi.org/10.1007/ s12571-020-01099-8

van Ittersum, M. K., Cassman, K. G., Grassini, P., Wolf, J., Tittonell, P., \& Hochman, Z. (2013). Yield gap analysis with local to global relevance - a review. Field Crops Research, 143, 4-17.

van Ittersum, M. K., van Bussel, L. G. J., Wolf, J., Grassini, P., van Wart, J., Guilpart, N., et al. (2016). Can sub-Saharan Africa feed itself? Proceedings of the National Academy of Sciences, 113(52), 14964-14969. https://doi.org/10.1073/pnas.1610359113

van Wijk, M., Hammond, J., Gorman, L., Adams, S., Ayantunde, A., Baines, D., et al. (2020). The Rural Household Multiple Indicator Survey, data from 13,310 farm households in 21 countries. Scientific Data, 7, 46. https://doi.org/10.1038/s41597-41020-4038841598, https://doi.org/10.1038/s41597-020-0388-8

van Wijk, M. T., Hammond, J., Frelat, R., \& Fraval, S. (2019). Unequal Access to Land: Consequences for the Food Security of Smallholder Farmers in Sub Saharan Africa. In P. Ferranti, E. M. Berry, \& J. R. Anderson (Eds.), Encyclopedia of Food Security and Sustainability, vol. 1 (pp. 556-561, Vol. Vol 1). Amsterdam: Elsevier.

Vollset, S. E., Goren, E., Yuan, C.-W., Cao, J., Smith, A. E., Hsiao, T., et al. (2020). Fertility, mortality, migration, and population scenarios for 195 countries and territories from 2017 to 2100 : A forecasting analysis for the Global Burden of Disease Study. The Lancet. https://doi.org/10.1016/S0140-6736(20)30677-2
Vorley, B. (2002). Sustaining Agriculture: Policy, Governance, and the Future of Family-based Farming (pp. 1-196). IIED.

Vorley, B., del Pozo-Vergnes, E., \& Barnett, A. (2012). Small producer agency in the globalised market: Making choices in a changing world. IIED Report (pp. 1-82). London: International Institute for Environment and Development.

Waha, K., van Wijk, M. T., Fritz, S., See, L., Thornton, P. K., Wichern, J., et al. (2018). Agricultural diversification as an important strategy for achieving food security in Africa. Global Change Biology, 74(1-3), 19-11. https://doi.org/10.1111/gcb.14158

Weisell, R., \& Dop, M. C. (2012). The Adult Male Equivalent concept and its application to household consumption and expenditures surveys (HCES). Food and Nutrition Bulletin, 33(3_suppl2), S157-S162. https://doi.org/10.1177/15648265120333S203

Wichern, J., Descheemaeker, K., Giller, K. E., Ebanyat, P., Taulya, G., \& van Wijk, M. T. (2019). Vulnerability and adaptation options to climate change for rural livelihoods - A country-wide analysis for Uganda. Agricultural Systems, 176, 102663. https://doi.org/ 10.1016/j.agsy.2019.102663

Wichern, J., Wijk, M. T., Descheemaeker, K., Frelat, R., Asten, P. J. A., \& Giller, K. E. (2017). Food availability and livelihood strategies among rural households across Uganda. Food Security, 9, 1385-1403. https://doi.org/10.1007/s12571-017-0732-9

World Bank. (2020). Microdata Library, Living Standards Measurements Study. Available from https://microdata.worldbank.org/ index.php/catalog/lsms. Washington, DC: World Bank.

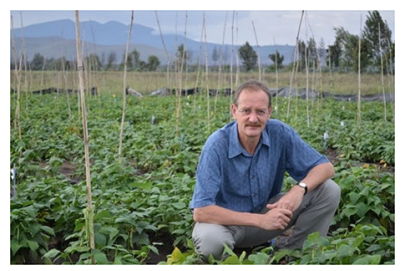

Ken Giller is Professor of Plant Production Systems at Wageningen University. He leads a group of scientists with profound experience in applying systems analysis to explore future scenarios for land use with a focus on food production. Ken's research focuses on smallholder farming systems in sub-Saharan Africa, and in particular problems of soil fertility and the role of nitrogen fixation in tropical legumes, with emphasis on the temporal and spatial dynamics of resources within crop/livestock farming systems and their interactions. He is author of the standard text "Nitrogen Fixation in Tropical Cropping Systems" published in second edition in 2001. He is co-chair of the Thematic Network 7 on Sustainable Agriculture and Food Systems of the Sustainable Development Solutions Network (SDSN) of the United Nations and a member of the Unilever Sustainable Sourcing Advisory Board. Ken joined Wageningen University as Chair of Plant Production Systems in 2001 after holding professorships at Wye College, University of London, and the University of Zimbabwe

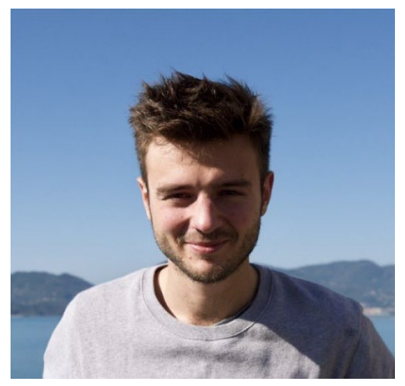

Thomas Delaune is a research assistant at the Plant Production Systems group of Wageningen University. He recently graduated in agricultural sciences at the Ecole Superieure d'Agriculture in Angers, France and in crop sciences at Wageningen Unversity, Netherlands. With a strong interest in data analysis, geoinformation sciences, and statistics, his works currently focuses on the analysis of smallholder farm-

ing systems in sub-Saharan Africa. He previously held a position of research assistant at the National Institute of Agricultural Research and 
Environment (INRAE) in France where his research focused on the relationships between crop pests and landscape composition.

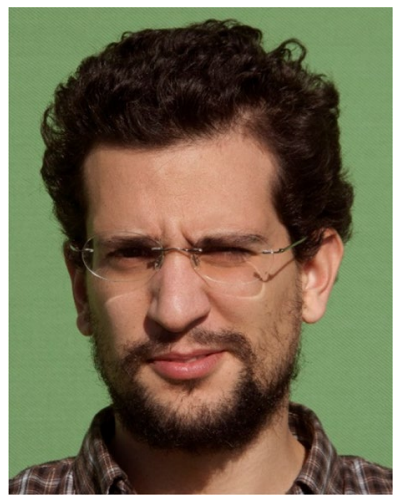

João Vasco Silva is systems agronomist at the International Maize and Wheat Improvement Center (CIMMYT) based in Harare, Zimbabwe and a guest researcher at the Plant Production Systems Group, Wageningen University (WU). João's expertise includes yield gap and resource use efficiency analysis, farming systems research and integrated assessments at field, farm, and regional levels. João holds a PhD from WU with a thesis focusing on explaining yield gaps at farm(ing) systems level including case studies on crop-livestock systems in Ethiopia, rice farming in the Philippines and arable farming in the Netherlands. This was followed by a post-doc at WU as part of a JPI-funded project aiming to identify opportunities for increasing water and nutrient use efficiencies in Europe and North Africa. João is currently involved in different research projects in East and Southern Africa focusing on guiding investments in acid soil management and on sustainable intensification of farming systems in the region.

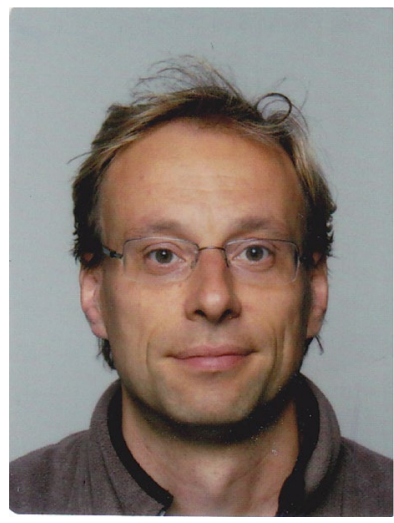

Mark van Wijk is a Senior Scientist at the International Livestock Research Institute, based in Quito, Ecuador. His research focuses on analysing farming systems in developing countries, trying to harvest the added value of combining modelling, experimental, participatory and statistical approaches. Recent work concentrated on developing tools to better target intervention options to improve income and diets of smallholder farmers, and quantify their adoption potential and observed effects. Previously he worked for almost 10 years as Assistant Professor at Wageningen University in the Plant Production Systems group.

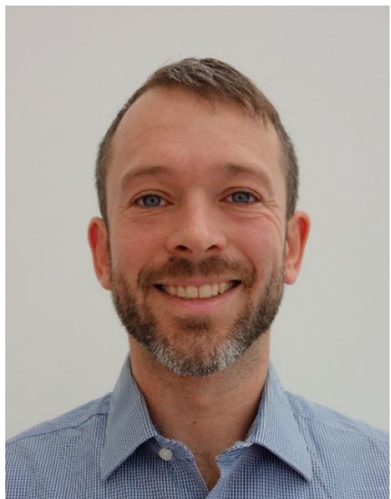

Jim Hammond is an inter-disciplinary scientist working on agriculture and sustainability issues, at the International Livestock Research Centre. The main themes of his work are the creation of a global harmonised database on smallholder farming practices and development outcomes, the development of userfriendly research tools to nudge researcher behaviours towards best practices, and analyses of interactions between elements of the farm-household system and the contexts in which farmers operate. Other research interests include agricultural innovation, the role of personal motivations in technology adoption, poverty dynamics, and approaches to multi-variate visualisations. Jim co-leads the RHoMIS initiative (see www.rhomis.org), holds an honorary position at the University of Bristol, and sits on the editorial advisory board of the Agricultural Systems journal.

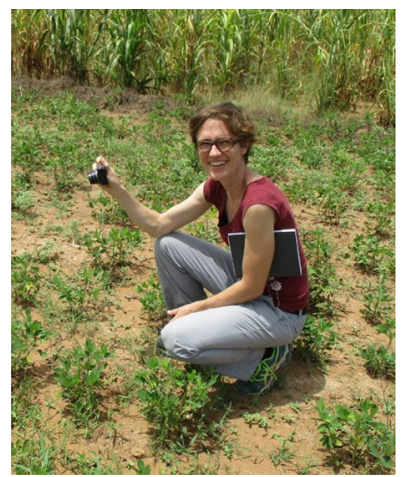

Katrien Descheemaeker is associate professor in the Plant Production Systems group of Wageningen University and Research (Netherlands). Her research focuses on farming systems analysis, soil-plant-animal interactions, and sustainable agricultural development, with a special interest in the functioning and dynamics of mixed crop-livestock systems. Current research combines experimental trial work with simulation modelling to identify and assess interventions for improved resource use efficiency and farm profitability, and reduced risks associated with climate and market variability. Across various projects on smallholder farming systems in sub-Saharan Africa, Dr. Descheemaeker and colleagues develop methods for participatory research with farmers and other stakeholders to increase the potential adoption and impact of technology and management options to increase farm productivity, food security and natural resource integrity.

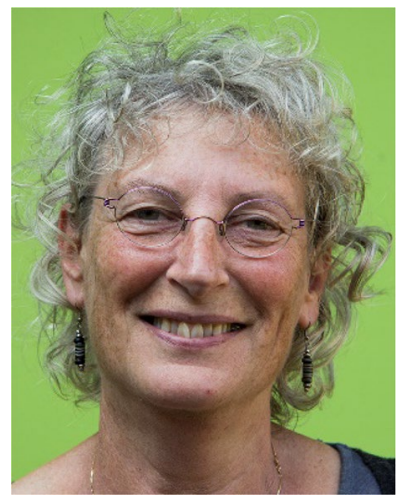

Gerrie van de Ven holds a $\mathrm{PhD}$ in Agricultural Science from Wageningen University. She is employed at the Plant Production Systems Group of that University. She combines research and teaching with a focus on farming systems analysis and optimization of land use systems related to all three dimensions of sustainability. Nutrient cycling, environmental impacts and indicators, the interaction between crops and livestock and economic consequences, both in the western world and in Africa, have her special attention. She previously worked at the Centre for Environmental Sciences at Leiden University and Plant Research International in Wageningen. Her scientific work has built on tools such as systems analysis and modelling approaches, mainly at the farm and regional level.

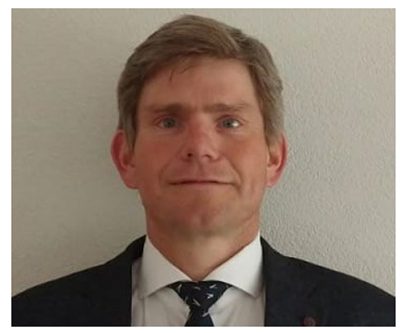

Antonius G.T.Schut(Tom) is associate professor at the Plant Production Systems group of Wageningen University in the Netherlands. After a bachelor in dairy science he graduated as spatial soil scientist at the Wageningen University. Tom's research focusses on the optimization of agricultural systems with sustainable intensification, adapting farm management to local conditions to improve efficiency and minimise environmental impacts. His work combines analysis of farming systems with simulation of crop growth and nutrient flows for fields, farms and farming systems. Tom's current research focusses on better nutrient management with balanced fertilization to improve the productivity of farms in smallholder 
systems and improved circularity of agriculture with integrated crop and livestock systems in intensified farming systems.

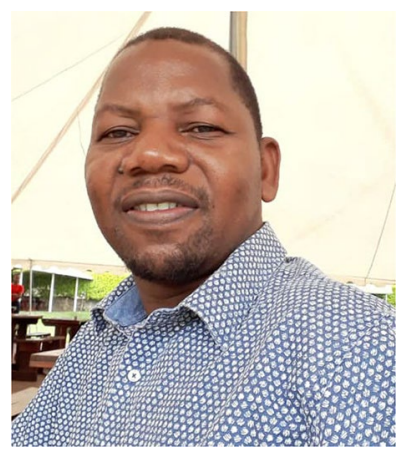

Regis Chikowo is an Associate Professor of Agronomy at University of Zimbabwe and Assistant Professor at Michigan State University, Plant Soil and Microbial Sciences Department. His interests are in agricultural technology development, delivery and use by smallholder farmers. He has over the years carried out basic and applied research on nutrient management on smallholder farms in southern Africa. Approaches that integrate legumes to tap into biological N2-fixation to sustain production on smallholder farms have been core his investigations. He currently invests much of his time leading the implementation of the Africa Research in Sustainable Intensification for the Next Generation (Africa RISING) project in Malawi, a Feed the Future collaborative effort between MSU and the International Institute of Tropical Agriculture (IITA); and the Dynamics of Soil Carbon Sequestration in Tropical and Temperate Agricultural systems (DSCATT) project, jointly implemented by the University of Zimbabwe and CIRAD.

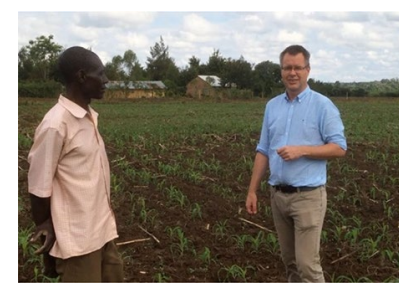

Jens A. Andersson is research fellow at the Plant Production Systems group of Wageningen University. Trained as a rural development sociologist / social anthropologist, Jens' research focuses on technology adoption and its social (equity) impacts, rural-urban linkages and rural livelihood diversification, the development of decision support tools for smallholder farmers, and agricultural change in smallholder farming systems in Africa. He has worked extensively in southern Africa, and held positions at the International Maize and Wheat Improvement Center (CIMMYT), the University of Amsterdam, and was affiliated to the University of the Witwatersrand, the University of Malawi, and the University of Zimbabwe. 